\title{
Comparative study of vent and seep macrofaunal communities in the Guaymas Basin
}

\author{
M. Portail ${ }^{1}$, K. Olu ${ }^{1}$, E. Escobar-Briones ${ }^{2}$, J. C. Caprais ${ }^{1}$, L. Menot $^{1}$, M. Waeles ${ }^{3}$, P. Cruaud ${ }^{4}$, P. M. Sarradin ${ }^{1}$, \\ A. Godfroy ${ }^{4}$, and J. Sarrazin ${ }^{1}$ \\ ${ }^{1}$ Institut Carnot Ifremer EDROME, Centre de Bretagne, REM/EEP, Laboratoire Environnement Profond, \\ 29280 Plouzané, France \\ ${ }^{2}$ Universidad Nacional Autónoma de México, Instituto de Ciencias del Mar y Limnología, AP 70-305, \\ Ciudad Universitaria, 04510 México, D. F. \\ ${ }^{3}$ Université de Bretagne Occidentale, IUEM, Lemar UMR CNRS 6539, 29280 Plouzané, France \\ ${ }^{4}$ Laboratoire de Microbiologie des Environnements Extrêmes, UMR6197, IFREMER, UBO, CNRS, Technopôle Brest Iroise, \\ 29280 Plouzané, France
}

Correspondence to: M. Portail (marie.portail@ifremer.fr)

Received: 10 April 2015 - Published in Biogeosciences Discuss.: 10 June 2015

Accepted: 10 August 2015 - Published: 21 September 2015

\begin{abstract}
Understanding the ecological processes and connectivity of chemosynthetic deep-sea ecosystems requires comparative studies. In the Guaymas Basin (Gulf of California, Mexico), the presence of seeps and vents in the absence of a biogeographic barrier, and comparable sedimentary settings and depths offers a unique opportunity to assess the role of ecosystem-specific environmental conditions on macrofaunal communities. Six seep and four vent assemblages were studied, three of which were characterised by common major foundation taxa: vesicomyid bivalves, siboglinid tubeworms and microbial mats. Macrofaunal community structure at the family level showed that density, diversity and composition patterns were primarily shaped by seep- and vent-common abiotic factors including methane and hydrogen sulfide concentrations, whereas vent environmental specificities (higher temperature, higher metal concentrations and lower $\mathrm{pH}$ ) were not significant. The type of substratum and the heterogeneity provided by foundation species were identified as additional structuring factors and their roles were found to vary according to fluid regimes. At the family level, seep and vent similarity reached at least $58 \%$. All vent families were found at seeps and each seepspecific family displayed low relative abundances $(<5 \%)$. Moreover, $85 \%$ of the identified species among dominant families were shared between seep and vent ecosystems. This
\end{abstract}

study provides further support to the hypothesis of continuity among deep-sea seep and vent ecosystems.

\section{Introduction}

Cold-seep ecosystems are related to active and passive margins and along-transform faults, whereas hydrothermal vents occur along mid-ocean ridge systems, back-arc basins and off-axis submarine volcanoes. According to their geological contexts, these ecosystems involve distinct geochemical processes that give rise to fluid emissions from beneath the seafloor. At seeps, high pore-water pressures within sediments result in the ascent of interstitial fluids that are enriched in hydrocarbons (e.g. methane). As these fluids reach the upper sediment layers, methane is partly oxidised by microbial consortia coupling an anaerobic oxidation of methane (AOM) with sulfate reduction that produces hydrogen sulfides (Boetius et al., 2000). In contrast, at vents, seawater penetrates the ocean crust fissures and heats up until advection processes initiate the rise of hot fluids (up to $400^{\circ} \mathrm{C}$ ) on the seafloor. The fluid composition becomes highly complex in contact with subsurface rocks, with enriched concentrations in trace, minor and major elements, methane, hydrogen sulfide, hydrogen gas and dissolved metals (Von Damm, 1995; Jannasch and Mottl, 1985). Although seeps and vents 
belong to two different geological contexts, both ecosystems are characterised by fluid emissions that present unusual properties, such as the presence of high concentrations of toxic compounds, steep physicochemical gradients and significant temporal variation at small spatial scales (Tunnicliffe et al., 2003). Furthermore, they both generate energy-rich fluids that sustain high local microbial chemosynthetic production in deep-sea ecosystems, which are usually food-limited (Smith et al., 2008). There, bacteria and archaea rely mainly on the oxidation of methane and hydrogen sulfide, which are the two most common reduced compounds in vents and seeps (McCollom and Shock, 1997; Dubilier et al., 2008; Fisher, 1990).

As a result, these chemosynthetic ecosystems share many ecological homologies. They harbour macrofaunal communities that are heterogeneously distributed in a mosaic of dense assemblages defined by the presence of foundation species. These foundation species include dense microbial mats dominated by Beggiatoa, siboglinid polychaetes, vesicomyid and bathymodiolid bivalves, alvinellid tube-dwelling worms, and several gastropod families (Govenar, 2010). Globally, vent and seep communities share elevated faunal densities, a relatively low taxonomic diversity and a high level of endemism in comparison to non-chemosynthetic deep-sea ecosystems (Tunnicliffe and Fowler, 1996; Sibuet and Olu, 1998; Carney, 1994). Vent and seep communities also share some families and genera, presenting evolutionary connections via common ancestors, with many transitions between vent and seep habitats over geological time (Tunnicliffe et al., 1998; Tyler et al., 2002). Growing evidence of evolutionary and functional homologies rapidly highlighted potential links between the two ecosystems. Further support for this hypothesis was provided by the presence of species shared between seeps and vents and by the discovery of additional chemosynthetic stepping-stones such as large organic falls (Smith and Baco, 2003; Smith and Kukert, 1989). Moreover, macrofaunal communities at a recently discovered hybrid seep and vent ecosystem called a "hydrothermal seep", associated with a subducting seamount on the convergent Costa Rica margin, harbours both seep and vent features, thus providing additional support for the hypothesis of continuity among reducing ecosystems (Levin et al., 2012).

Despite these numerous homologies, comparison of seeps and vents at the macrofaunal community level have revealed striking differences. Comparative studies have shown that seeps exhibit usually higher diversity and lower endemism than vents (Sibuet and Olu, 1998; Turnipseed et al., 2003, 2004; Levin, 2005; Bernardino et al., 2012). Furthermore, the number of species shared on a global scale between the two ecosystems is less than $10 \%$ of the total recorded species (e.g. Tunnicliffe et al., 2003, 1998; Sibuet and Olu, 1998). In addition, a recent review of several sedimented sites in the Pacific Ocean also points to strong dissimilarities between vent and seep macrofaunal communities even at the family level (up to $93 \%$; Bernardino et al., 2012). These strong differences are assumed to be partly shaped by large-scale factors. Seep and vent biogeographic isolation and subsequent evolutionary divergence, as well as the closer proximity of seeps to continents (and the resulting settlement of background macrofauna) may play an important role in structuring these communities (Carney, 1994; Baker et al., 2010). Nevertheless, around Japan, a region where a total of 42 seep and vent ecosystems are found in close proximity, the similarity between seep and vent species reached only $28 \%$ (Watanabe et al., 2010; Sibuet and Olu, 1998; Nakajima et al., 2014). Therefore, other factors may contribute to the strong differences among communities. Despite strong variation in environmental conditions in each type of ecosystem, due to the multiplicity of geological contexts and environmental settings in which seep and vent occur, vents are usually considered as less favourable to life than seeps. Vent fluids usually exhibit greater temperature anomalies, higher metal concentrations, lower $\mathrm{pH}$ and oxygen concentrations, as well as higher outflow rates and temporal instability, than seep fluids (Tunnicliffe et al., 2003; Sibuet and Olu, 1998; Herzig and Hannington, 2000). Therefore, ecological processes driving community dynamics and regulating community structure may indeed differ in seeps and vents. Although reliance on chemosynthetic production and tolerance to environmental conditions underlie the predominant role of fluid input in both ecosystems, additional vent-specific factors may lead to distinct community structure patterns among ecosystems and thus explain, at least partly, the seep and vent faunal discrepancies. Nonetheless, the effect of vent-specific environmental factors on the structure of macrofaunal communities are not well known due to strong correlations among physicochemical factors (Johnson et al., 1988), preventing estimation of their respective effects (Govenar, 2010; Sarrazin et al., 1999). Overall, the key questions that remain to be addressed involve the relative influences of biogeographical and environmental barriers on vent and seep macrofaunal community dissimilarities (Bernardino et al., 2012).

The Guaymas Basin is one of the only areas in the world that harbours both ecosystems in close proximity. Located in the central portion of the Gulf of California, Mexico, the Guaymas Basin is a young spreading centre where hydrothermal vents are found at less than $60 \mathrm{~km}$ from cold seeps without a biogeographic barrier, at comparable depths (around $2000 \mathrm{~m}$ ) and in a similar sedimentary setting (Simoneit et al., 1990; Lonsdale et al., 1980). Therefore, this study site offers a unique opportunity to assess and compare the role of local seep and vent environmental factors on macrofaunal communities.

Here, we compared the structure (abundance, diversity and composition) of Guaymas seep and vent macrofaunal assemblages in relation to their environmental conditions. The following questions were addressed: (1) what are the similarities and differences in geochemistry, microbial processes and potential engineering effects of foundation species within 
and between ecosystems? (2) Does the structure of seep and vent macrofaunal communities differ and which abiotic and biotic factors can best explain community structure patterns? (3) What is the level of macrofaunal overlap between the two ecosystems and how does it relate to environmental conditions?

We tested whether macrofaunal density, diversity and composition patterns are ecosystem-dependent. We assumed that macrofaunal composition overlap among seeps and vents will be larger among low fluid-flux than among high fluidflux sites. Finally, we hypothesised that other factors such as the nature of the substratum and the engineering role of foundation species may further add a non-negligible heterogeneity within both ecosystems.

\section{Materials and methods}

\subsection{Study area}

This study focused on three areas in the Guaymas Basin located in the central portion of the Gulf of California (Fig. 1): (1) cold seeps on the Sonora margin transform faults $\left(27^{\circ} 36^{\prime} \mathrm{N}, 111^{\circ} 29^{\prime} \mathrm{W}\right)$ at $1550 \mathrm{~m}$ depth, (2) a large hydrothermal field on the Southern Trough depression $\left(27^{\circ} 00^{\prime} \mathrm{N}, 111^{\circ} 24^{\prime} \mathrm{W}\right)$ at $1900 \mathrm{~m}$ depth and (3) an offaxis reference site $\left(27^{\circ} 25^{\prime} \mathrm{N}, 111^{\circ} 30^{\prime} \mathrm{W}\right)$ located at $1500 \mathrm{~m}$ depth.

The Guaymas Basin, due to the high biological productivity of surface water, is lined with a $1-2 \mathrm{~km}$ layer of organic-rich, diatomaceous sediments (Schrader, 1982; Calvert, 1966).

The Sonora margin transform faults are located along the eroding crest of a steep anticline (Simoneit et al., 1990; Paull et al., 2007). They are structurally similar to continental shelf pockmarks and have been named hydrocarbon seeps due to the emission of methane and higher hydrocarbon components. The fluid geochemistry is still poorly known (Simoneit et al., 1990). Extensive carbonate concretions have been reported and studied in this area (Paull et al., 2007). Macrofaunal communities of the Sonora seep are mostly unknown and only foundation species (vesicomyid bivalves and siboglinid tubeworms) have been described (Simoneit et al., 1990; Paull et al., 2007).

The Southern Trough spreading segment is characterised by magmatic intrusions that drive an upward hydrothermal flux through the organic-rich overlying sediments and maintain a recharging seawater circulation (Gieskes et al., 1982; Lonsdale and Becker, 1985; Fisher and Becker, 1991). End-member fluid composition is enriched in hydrogen sulfide, low-molecular-weight organic acids, petroleum-like aliphatic and aromatic hydrocarbons, ammonia, and methane (Kawka and Simoneit, 1987, 1990; Simoneit et al., 1996; Leif and Simoneit, 1995), but has relatively low metal concentrations (Von Damm et al., 1985). Vent fluids emanate ei- ther diffusely through the water-sediment interface at temperatures less than $200^{\circ} \mathrm{C}$ or through mounds and chimneys rising over the seafloor where temperatures can reach up $350^{\circ} \mathrm{C}$ (Von Damm et al., 1985). The foundation species of this vent area have been described (Soto and Grassle, 1988; Ruelas-Inzunza et al., 2003, 2005; Lonsdale and Becker, 1985; Demina et al., 2009), but only few studies have included the associated macrofaunal community (Grassle et al., 1985; Soto, 2009; Blake and Hilbig, 1990).

The Biodiversity and Interactions in the Guaymas Basin (BIG) cruise was held in 2010 on board the oceanographic vessel R/V L'Atalante equipped with the Nautile submersible. The autonomous underwater vehicle (AUV) AsterX explorations of the area resulted in the fine-scale mapping of active seep and vent sites (Fig. 1). In the vent field, we studied two hard substrate edifices, Rebecca's Roots and Mat Mound as well as two sedimented vents, Mega Mat and the newly discovered Morelos site. At the seep, all study sites were newly discovered. Juarez site was characterised by carbonate concretions overlying soft sediments whereas Vasconcelos and Ayala were related to soft-sediment sites. All study sites are found deeper than the main oxygen minimum zone $\left(<0.5 \mathrm{mLL}^{-1}\right)$ that is found between 650 and $1100 \mathrm{~m}$ along the north-east Pacific margins from the state of California to Oregon (Helly and Levin, 2004) and within the Guaymas Basin (Campbell and Gieskes, 1984). Oxygen measurements made in overlaying waters at our seep and vent study sites showed oxygen concentrations of 1.38 and $1.43 \mathrm{~mL} \mathrm{~L}^{-1}$, respectively.

\subsection{Sampling design}

The Nautile submersible was used to identify and sample specific assemblages, characterised by the presence of foundation species, within seep and vent sites. An off-axis site was also sampled and used as a background reference site of the Guaymas Basin (G_Ref).

\section{Sonora margin}

A total of six seep assemblages were studied $S_{-}$(Fig. 2). Three assemblages were sampled at the Vasconcelos site: (1) S_Mat characterised by microbial mats dominated by the Beggiatoa genus, (2) S_Gast characterised by Hyalogyrina sp. gastropods forming grey mats surrounding the microbial mats, and (3) S_VesA characterised by the dominance of Archivesica gigas vesicomyids that were found at the periphery of white and grey mats. At Ayala, another type of Vesicomyidae assemblage was sampled: (4) S_VesP characterised by the dominance of Phreagena soyoae (syn. kilmeri). Some specimens of Calyptogena pacifica vesicomyids were sampled in qualitative peripheral samples at S_VesA and S_VesP. Finally, at the Juarez site, two assemblages were sampled: (5) S_Sib characterised by the siboglinid tubeworms Escarpia spicata and Lamellibrachia barhami estab- 


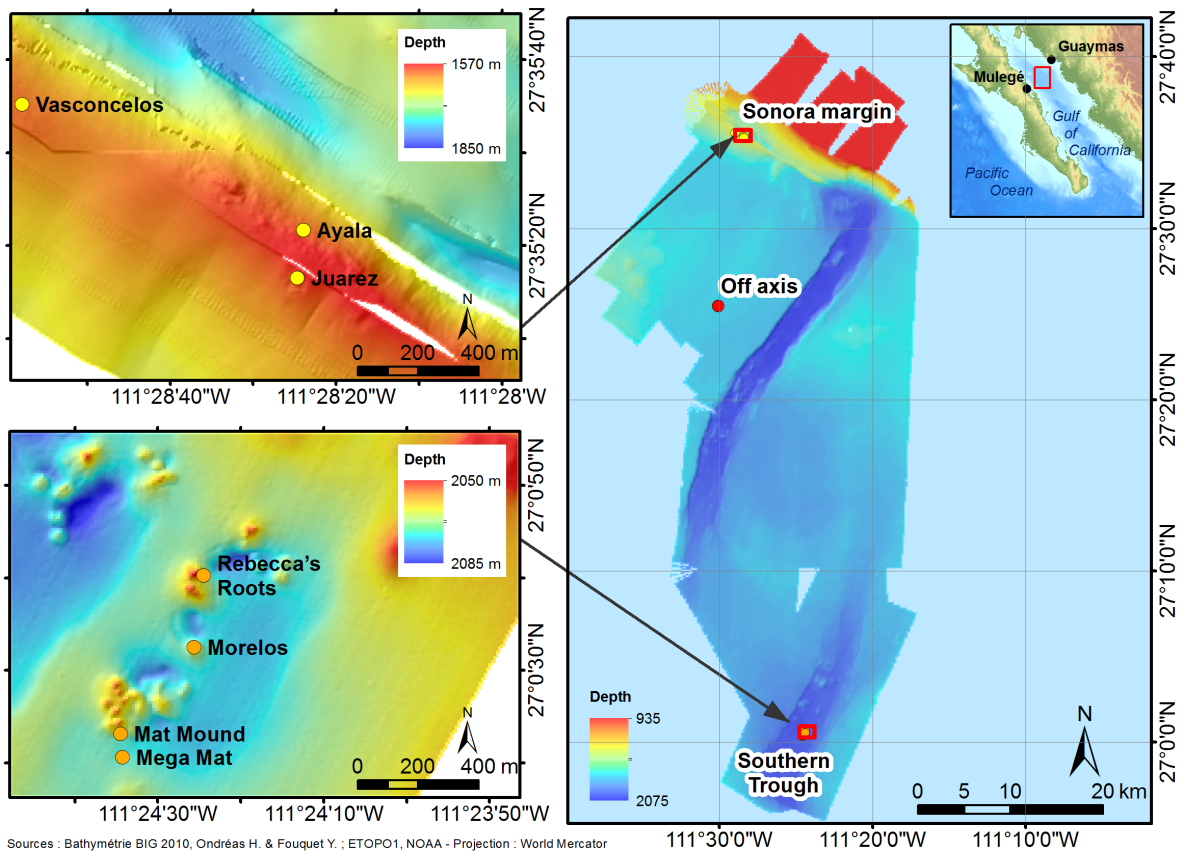

Figure 1. Localisation of the study sites on the Sonora margin cold seeps (Ayala, Vasconcelos and Juarez sites), the Southern Trough hydrothermal vents (Rebecca's Roots, Mat Mound, Morelos and Mega Mat sites) and the Guaymas Basin off-axis reference site.

lished on carbonate concretions and (6) S_Sib_P corresponding to the presence of reduced sediments in the immediate periphery of S_Sib.

\section{Southern Trough}

A total of four vent assemblages were studied V_(Fig. 2). At the Mega Mat site, a microbial mat assemblage was sampled: (1) V_Mat, characterised by the presence of white Beggiatoa sp. microbial mats surrounded by yellow Beggiatoa sp. mats. At the Morelos site, a Vesicomyidae assemblage was sampled: (2) V_VesA characterised by A. gigas vesicomyid. At the Rebecca's Roots site, an alvinellid assemblage was sampled on the $13 \mathrm{~m}$ edifice: (3) V_Alv characterised by the presence of Paralvinella grasslei and P. bactericola. Finally, at the Mat Mound site, a siboglinid assemblage on a 3-4 m high sulfide mound was sampled: (4) V_Sib characterised by Riftia pachyptila embedded in microbial mats.

\subsection{Characterisation of physicochemical conditions}

To characterise the habitats of the different assemblages, all sampling and measurements were performed in close proximity to the organisms (Table 1). Habitat temperatures were recorded using the Nautile temperature probe. Water samples were collected in Fenwal Transfer Pack ${ }^{\mathrm{TM}}$ containers (2 L, Baxter) using the PEPITO sampler implemented on the Nautile submersible. The samples were pumped with a titanium-Tygon inlet associated with the Nautile temperature probe. Immediately after submersible recovery, the contain- ers were brought to a clean laboratory and filtered through $0.45 \mu \mathrm{m}$ Millipore ${ }^{\circledR}$ HATF filters for further quantification of dissolved metals ( $\mathrm{Fe}, \mathrm{Mn}$ and $\mathrm{Cu}$ ). $\mathrm{Fe}$ and $\mathrm{Mn}$ were determined using inductively coupled plasma-optical emission spectrometry (ICP-OES; Ultima 2, Horiba Jobin Yvon, Pôle Spectrométrie Océan), whereas $\mathrm{Cu}$ was measured using a gold microwire electrode (Salaün and van den Berg, 2006). $\mathrm{pH}$ measurements (NBS scale) were performed on board using a Metrohm glass electrode. Methane concentrations were quantified using the headspace technique (HSS 86.50, DaniInstruments) and a gas chromatograph (Perichrom 2100, Alpha MOS) equipped with a flame-ionisation detector (Sarradin and Caprais, 1996).

For characterising soft-sediment habitats, we took additional temperature measurements within the sediment layer, using a $50 \mathrm{~cm}$ long graduated temperature sensor as well as push-core samples. The pore waters were extracted from each $0-2 \mathrm{~cm}$ section along cores and analysed for methane, hydrogen sulfide, sulfate and ammonium concentrations following procedures described in (Caprais et al., 2010; Vigneron et al., 2013; Russ et al., 2013). The CALMAR benthic chamber (Caprais et al., 2010) was used to characterise the methane flux at the interface of vesicomyid assemblages.

Data on physicochemical factors were analysed for all habitats when available and for soft-sediment habitats only. To compare all habitats, physicochemical factors from water measurements on hard substratum habitats were compared against physicochemical factors from sediment pore waters in soft-sediment habitats. For both types of substrata, physic- 
Table 1. Abbreviations, sampling details and locations of the different assemblages sampled in the Guaymas Basin. Blade corers sample a surface of $18 \mathrm{~cm}^{2}$ for the small blade cores (SBC) and $360 \mathrm{~cm}^{2}$ for the large cores (LBC), whereas tube corers (TC) sample a surface of $26 \mathrm{~cm}^{2}$. GS: ground surface sampled.

\begin{tabular}{|c|c|c|c|c|c|c|}
\hline Abbreviation & Latitude & Longitude & $\begin{array}{l}\text { Foundation } \\
\text { taxa }\end{array}$ & Substrata & $\begin{array}{l}\text { Physicochemical } \\
\text { characterisation }\end{array}$ & Faunal sampling \\
\hline \multicolumn{7}{|c|}{ Reference assemblage } \\
\hline G_ref & $27^{\circ} 25.483^{\prime} \mathrm{N}$ & $111^{\circ} 30.076^{\prime} \mathrm{W}$ & None & Soft & $\begin{array}{l}2 \mathrm{TC} \\
5 \text { PEPITO } \\
2 \text { CALMAR }\end{array}$ & $\begin{array}{l}\text { Macrofauna: } 4 \text { SBC } \\
\text { Microbiota: } 1 \text { TC }\end{array}$ \\
\hline \multicolumn{7}{|c|}{ Seep assemblages } \\
\hline S_VesP & $27^{\circ} 35.365^{\prime} \mathrm{N}$ & $111^{\circ} 28.395^{\prime} \mathrm{W}$ & P. soyoae & Soft & $\begin{array}{l}1 \mathrm{TC} \\
7 \text { PEPITO } \\
2 \text { CALMAR }\end{array}$ & $\begin{array}{l}\text { Macrofauna: } 3 \text { LBC } \\
\text { Microbiota: } 1 \text { TC }\end{array}$ \\
\hline S_VesA & $27^{\circ} 35.587^{\prime} \mathrm{N}$ & $111^{\circ} 28.963^{\prime} \mathrm{W}$ & A. gigas & Soft & $\begin{array}{l}1 \mathrm{TC} \\
2 \text { CALMAR } \\
3 \text { PEPITO }\end{array}$ & $\begin{array}{l}\text { Macrofauna: } 3 \text { LBC } \\
\text { Microbiota: } 1 \text { TC }\end{array}$ \\
\hline S_Mat & $27^{\circ} 35.580^{\prime} \mathrm{N}$ & $111^{\circ} 28.986^{\prime} \mathrm{W}$ & Beggiatoa spp. & Soft & $\begin{array}{l}2 \mathrm{TC} \\
12 \text { PEPITO }\end{array}$ & $\begin{array}{l}\text { Macrofauna: } 3 \text { LBC } \\
\text { Microbiota: } 1 \text { TC }\end{array}$ \\
\hline S_Gast & $27^{\circ} 35.583^{\prime} \mathrm{N}$ & $111^{\circ} 28.982^{\prime} \mathrm{W}$ & Hyalogyrina $\mathrm{sp}$ & Soft & $2 \mathrm{TC}$ & Macrofauna: 1 SBC \\
\hline S_Sib & $27^{\circ} 35.274^{\prime} \mathrm{N}$ & $111^{\circ} 28.406^{\prime} \mathrm{W}$ & $\begin{array}{l}\text { E. spicata, } \\
\text { L. barhami }\end{array}$ & Hard & 6 PEPITO & $\begin{array}{l}\text { Suction sampler }+ \\
\text { submersible arm grab } \\
\text { GS: } 694 \mathrm{~cm}^{2}\end{array}$ \\
\hline S_Sib_P & $27^{\circ} 35.273^{\prime} \mathrm{N}$ & $111^{\circ} 28.407^{\prime} \mathrm{W}$ & $\begin{array}{l}\text { None (S_Sib } \\
\text { periphery) }\end{array}$ & Soft & $1 \mathrm{TC}$ & $\begin{array}{l}\text { Macrofauna: } 4 \text { SBC } \\
\text { Microbiota: } 1 \text { TC }\end{array}$ \\
\hline \multicolumn{7}{|c|}{ Vent assemblages } \\
\hline V_VesA & $27^{\circ} 00.547^{\prime} \mathrm{N}$ & $111^{\circ} 24.424^{\prime} \mathrm{W}$ & A. gigas & Soft & $\begin{array}{l}2 \mathrm{TC} \\
8 \text { PEPITO } \\
2 \text { CALMAR }\end{array}$ & $\begin{array}{l}\text { Macrofauna: } 3 \text { LBC } \\
\text { Microbiota: } 1 \mathrm{TC}\end{array}$ \\
\hline V_Mat & $27^{\circ} 00.445^{\prime} \mathrm{N}$ & $111^{\circ} 24.530^{\prime} \mathrm{W}$ & Beggiatoa spp. & Soft & $1 \mathrm{TC}$ & $\begin{array}{l}\text { Macrofauna: } 2 \text { LBC } \\
\text { Microbiota: } 1 \text { TC }\end{array}$ \\
\hline V_Alv & $27^{\circ} 00.664^{\prime} \mathrm{N}$ & $111^{\circ} 24.412^{\prime} \mathrm{W}$ & $\begin{array}{l}\text { P. grasslei, } \\
\text { P. bactericola }\end{array}$ & Hard & 2 PEPITO & $\begin{array}{l}\text { Suction sampler } \\
\text { GS: } 720 \mathrm{~cm}^{2}\end{array}$ \\
\hline V_Sib & $27^{\circ} 00.386^{\prime} \mathrm{N}$ & $111^{\circ} 24.576^{\prime} \mathrm{W}$ & R. pachyptila & Hard & 5 PEPITO & $\begin{array}{l}\text { Suction sampler }+ \\
\text { submersible arm grab } \\
\text { GS: } 1134 \mathrm{~cm}^{2}\end{array}$ \\
\hline
\end{tabular}

ochemical factors were separated into "interface" and "maximum" concentrations, which represented fluid input proxies. On hard substrata, the interface values corresponded to the measurements made close to the substratum and maximum values were selected from all measurements made within the three-dimensional assemblages. Similarly, softsediment physicochemical conditions from pore waters were summarised as interface values $(0-2 \mathrm{~cm})$ and maximum values along the depth of the cores $(10 \mathrm{~cm})$.

\subsection{Quantification of sedimentary microbial populations using quantitative PCR}

At each location, a sediment push core was collected for microbiological analyses (Table 1). After recovery on board, sediment cores were immediately transferred to a cold room $\left(\sim 8^{\circ} \mathrm{C}\right)$ for sub-sampling. Sediment cores $(0-10 \mathrm{~cm})$ were sub-sampled in $2 \mathrm{~cm}$ thick layers and then frozen at $-80^{\circ} \mathrm{C}$ for subsequent total nucleic acid extraction. For each sample, total nucleic acids were extracted using a method modified from (Zhou et al., 1996) and detailed in (Cruaud et al., 2014). Archaeal and bacterial abundances were then estimated by 


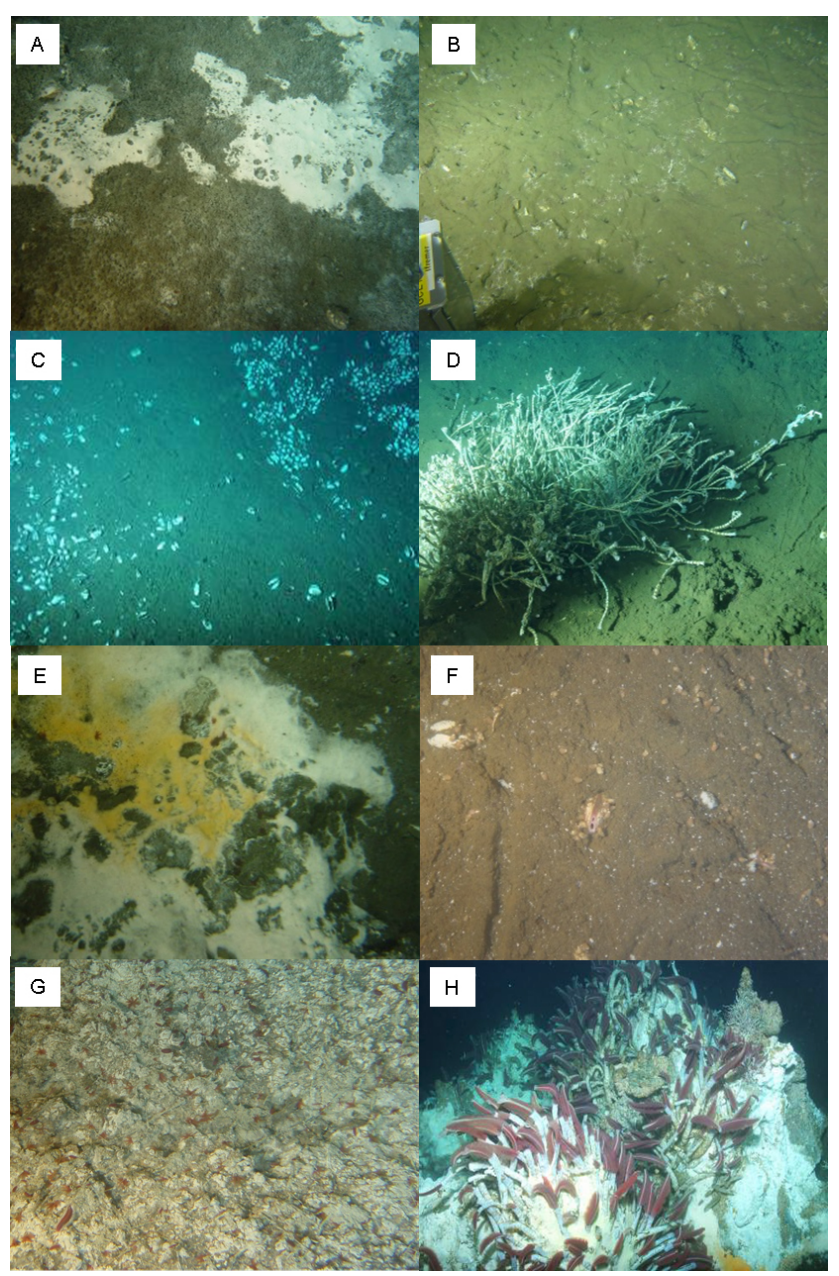

Figure 2. Images of studied assemblages at seeps: (a)S_Mat and S_Gast, (b) S_VesA, (c) S_VesP, (d) S_Sib and S_Sib_P and vents: (e) V_Mat, (f) V_VesA, (g) V_Alv and (h) V_Sib.

quantitative polymerase chain reaction (qPCR). Amplifications were performed with a Step One Plus instrument (Life Technologies, Gaithersburg, MD, USA) in a final volume of $25 \mu \mathrm{L}$ using PerfeCTa ${ }^{\circledR}$ SYBR $^{\circledR}$ Green SuperMix ROX (Quanta Bioscience), $1 \mathrm{ng}$ of crude nucleic acid extract (template) and primers with appropriate concentrations according to the manufacturer's instructions. The primers used targeted specific microbial groups potentially involved in AOM. Relative abundances of known clades of anaerobic methaneoxidisers (archaeal anaerobic methanotrophs ANME-1, -2 and -3; Vigneron et al., 2013) and their potential bacterial partners DSS (Desulfosarcina/Desulfococcus group), DBB (Desulfobulbus group) and SEEP-SRB2 (Vigneron et al., 2014) were estimated. Standard curves were obtained in triplicate with 10 -fold serial dilutions $\left(10^{5}-10^{9}\right.$ copies per $\left.\mu \mathrm{L}\right)$ of plasmids containing environmental 16S rRNA genes of selected microbial lineages. The efficiencies of the reactions were above $85 \%$ and coefficients of determination $\left(R^{2}\right)$ of standard curves were close to 0.99 . Samples were diluted un- til the crossing point decreased log-linearly with sample dilutions, indicating the absence of an inhibition effect. qPCR results were cumulated along the entire length of the sediment core and expressed in copy number per gram of sediment.

\subsection{Macrofaunal community characterisation}

For soft substrata, blade corers $\left(180\right.$ or $360 \mathrm{~cm}^{2}$ ) were used to collect macrofauna (Table 1). On hard substrata, suction sampling before and after grab sampling with the submersible arm was used to collect the macrofauna and samples were placed in individual isothermal boxes. Although quantitative sampling of soft-sediment communities is straightforward with box corers, it is much more difficult to carry out on hard substrata. Video imagery is therefore used to assess the sampled surface. Numerical images taken before and after sampling were analysed using the Image J Software (see protocol in Sarrazin et al., 1997). Each sampled area was outlined and analysed 5 times to estimate mean surface values. This method probably underestimates the sampled surfaces due to the omission of relief or thickness of the macrofaunal coverage, inducing a bias in density estimates but no other method is yet available to quantitatively sample the macrofauna on hard substrata in the deep sea (Gauthier et al., 2010).

\subsubsection{Foundation species}

The distribution of foundation species was used a priori to define assemblages; we therefore excluded them from the community level study. Furthermore, these species can have both allogenic (e.g. bioturbation, sulfide pumping) and autogenic (e.g. habitat provision) engineering effects on the structure of macrofaunal communities (Cordes et al., 2010; Govenar, 2010). For consistent approximation of potential engineering effects across assemblages, we used their size, biomass (ash-free dry weight (AFDW) without tubes for siboglinids and without shells for vesicomyids and gastropods) and densities of foundation species as proxies.

\subsubsection{Macrofaunal communities}

All sediment sub-samples and hard substrata samples were sieved through a stack of four sieves of decreasing mesh sizes $(1,0.5,0.3$ and $0.25 \mathrm{~mm})$. The samples were fixed in $4 \%$ buffered formaldehyde for $24 \mathrm{~h}$ then preserved in $70 \%$ alcohol. In the laboratory, only macrofauna $(>250 \mu \mathrm{m})$ sensu stricto (i.e. excluding meiofaunal taxa; Hessler and Jumars, 1974; Dinet et al., 1985) were sorted, counted and identified. Identification was done to the lowest taxonomic level possible with particular attention paid to dominant taxa. Polychaete morphological identifications at the species level were not systematically reached due to the sieving process which often damages the organisms. Bivalve identifications were made in collaboration with Elena Krylova (Shirshov Institute of Oceanology, Russia), although a large number of juveniles could not be identified to the species level. Gastropods 
were exhaustively characterised in collaboration with Anders Warén (Swedish Museum of Natural History, Sweden). Because it was not always possible to determine to the species level, comparisons of the macrofaunal community were done at the family level, except for some taxa with low contributions to macrofaunal densities, such as Aplacophora, Sipuncula, Scaphopoda, Nemertina, Cumacea, Tanaidacea and Amphipoda.

\subsection{Data analyses}

At the assemblage scale, considering the low level of replication within some assemblages ( $n$ varied between 1 and 4, Table 1) and differences in sampling strategies between soft and hard substrata, data analyses mainly relied upon descriptive statistics. Rarefaction curves and Hurlbert's ES(n) diversity index were computed using the Biodiversity $\mathrm{R}$ package (Kindt and Coe, 2005) and the functions in Gauthier et al. (2010) on pooled abundances per assemblage. The $\mathrm{ES}(\mathrm{n})$ measure of diversity was used because this index is the most suitable for non-standardised sample sizes (Soetaert and Heip, 1990). Spearman rank correlations were carried out on physicochemical variables, foundation species descriptors and associated macrofaunal community density and ES(n) diversity. Two levels of analysis were applied: one considering all assemblages sampled (hard and soft) and a subset focusing on soft-substratum assemblages, thereby allowing the addition of supplementary physicochemical variables and the abundance of microbes potentially involved in AOM. Parametric regression models were tested for ES(n) and macrofaunal density in relation to physicochemical conditions to compare our data with previous studies.

Community composition analyses were based on Hellinger-transformed family densities to conserve Hellinger, rather than Euclidian, distances in the principal component analysis (PCA). The Hellinger distance gives a lower weight to dominant taxa and avoids considering double absence as an indicator of similarity between samples (Legendre and Gallagher, 2001). Canonical redundancy analyses (RDA), considering all assemblages, included hard and soft substrata qualitative variable as well as normalised physicochemical variables and foundation species descriptors. On soft substrata, a co-inertia analysis (CIA) was carried out first on normalised physicochemical factors and the abundance of microbial groups potentially involved in AOM. The CIA summarises most of the covariance between physicochemical variables and microbial processes across sedimentary habitats into a limited number of independent variables (the first $x$ axes of the CIA). These new variables, considered to depict the biogeochemical environment of each habitat, were then used as explanatory variables in a RDA, together with the proxies of the engineering effects of foundation species. For all RDA analyses, forward selection with a threshold $p$ value of 0.1 was used to sort the significant explanatory variables. The significance of
CIA and RDA were tested with permutation tests (Legendre and Legendre, 2012).

At the ecosystem level and among the three vesicomyid assemblages for which comparisons were possible, mean comparisons were done using the non-parametric Kruskal-Wallis test, followed by a least significant difference (LSD) rank test for pairwise comparisons (Steel and Torrie, 1997). The Sorensen index was used to estimate and compare the beta diversity of the seep and vent ecosystems based on presence/absence data. Sorensen dissimilarity was decomposed according to turnover and nestedness, which result from two antithetic processes, namely species replacement and species loss (Baselga, 2010).

All analyses were performed in the $\mathrm{R}$ environment (Bolker, 2012). Multivariate analyses were carried out using rdaTest function and vegan (Oksanen et al., 2015), ade4 (Dray and Dufour, 2007) and betapart (Baselga and Orme, 2012) packages.

\section{Results}

\subsection{Environmental description}

\subsubsection{Physicochemical conditions}

\section{All assemblages}

Temperature and methane concentrations were the only two physicochemical variables that were measured across all assemblages, including hard and soft substrata (Table 2). Interface and maximum values were always correlated $(R: 0.9$, $p<0.001)$. Thus, only maximal values are presented herein.

No temperature anomalies in comparison to ambient bottom seawater (which is $2.9^{\circ} \mathrm{C}$ in the Guaymas Basin) were found in seep assemblages. At vents, all assemblages showed temperature anomalies with maximum temperatures from

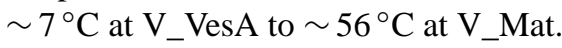

Maximum methane concentrations at G_Ref were low $(\sim 1 \mu \mathrm{M})$. At seeps, maximum methane concentrations ranged from $\sim 1 \mu \mathrm{M}$ to $800 \mu \mathrm{M}$, separating assemblages into two groups, one showing low concentrations (S_VesA, S_Sib_P, S_VesP and S_Sib) and the other high concentrations (S_Gast and S_Mat). At vents, methane concentrations were highly correlated to temperature $(R: 0.9, p<0.05)$. Maximum methane concentrations ranged from $\sim 50 \mu \mathrm{M}$ to $\sim 900 \mu \mathrm{M}$, with low concentrations found at V_VesA, high concentrations at V_Sib, V_Alv and the highest concentrations at V_Mat. While CALMAR measurements of fluid fluxes were not systematic, methane flux was null at $G_{-}$Ref and increased in vesicomyid assemblages from seeps to vents (Table 3). 
Table 2. Temperature and methane concentrations measured for all assemblages (pore-water measurements within soft sediment and water measurements above hard substratum) and hydrogen sulfide, ammonium and sulfate pore-water concentrations within soft sediment assemblages. Physico-chemical factors are summarised as substratum-water interface values and maximum values measured among assemblages. Highest values are highlighted in bold.

\begin{tabular}{lrrrrrrrrrr}
\hline Abbreviation & $\begin{array}{r}T_{\text {int }} \\
{ }^{\circ} \mathrm{C}\end{array}$ & $\begin{array}{r}T_{\max }{ }^{\circ} \mathrm{C} \\
\end{array}$ & $\begin{array}{r}{\left[\mathrm{CH}_{4}\right]_{\text {int }}} \\
\mu \mathrm{M}\end{array}$ & $\begin{array}{r}{\left[\mathrm{CH}_{4}\right]_{\max }} \\
\mu \mathrm{M}\end{array}$ & $\begin{array}{r}{\left[\mathrm{H}_{2} \mathrm{~S}\right]_{\text {int }}} \\
\mu \mathrm{M}\end{array}$ & $\begin{array}{r}{\left[\mathrm{H}_{2} \mathrm{~S}\right]_{\max }} \\
\mu \mathrm{M}\end{array}$ & $\begin{array}{r}{\left[\mathrm{NH}_{4}\right]_{\text {int }}} \\
\mu \mathrm{M}\end{array}$ & $\begin{array}{r}{\left[\mathrm{NH}_{4}\right]_{\max }} \\
\mu \mathrm{M}\end{array}$ & $\begin{array}{r}{\left[\mathrm{SO}_{4}^{2-}\right]_{\text {int }}} \\
\mathrm{mM}\end{array}$ & $\begin{array}{r}{\left[\mathrm{SO}_{4}^{2-}\right]_{\min }} \\
\mathrm{mM}\end{array}$ \\
\hline G_ref & 2.9 & 2.9 & 0.4 & 0.7 & 0.0 & 0.0 & 11.5 & 12.8 & 27.1 & $\mathbf{2 7 . 0}$ \\
S_VesP & 2.9 & 2.9 & 0.6 & 13.0 & 0.0 & 0.0 & 13.4 & 47.5 & 26.8 & 26.8 \\
S_VesA & 2.9 & 2.9 & 0.4 & 0.7 & 0.0 & 0.0 & 33.0 & 33.0 & 27.0 & 26.5 \\
S_Mat & 2.9 & 2.9 & $\mathbf{7 8 7}$ & 803 & $\mathbf{2 2 7 0 0}$ & $\mathbf{3 1 3 0 0}$ & 33.8 & 55.9 & 11.7 & 7.1 \\
S_Gast & 2.9 & 2.9 & 192 & 680 & 2470 & 15600 & 5.4 & 25.6 & 14.8 & 7.2 \\
S_Sib_P & 2.9 & 2.9 & 0.6 & 4.6 & 0.0 & 0.0 & 12.4 & 29.8 & $\mathbf{2 7 . 3}$ & 26.5 \\
V_VesA & 3.1 & 6.5 & 2.1 & 45.7 & 0.0 & 1700 & 32.6 & 384 & 27.2 & 24.7 \\
V_Mat & 3.2 & $\mathbf{5 5 . 5}$ & 220 & $\mathbf{8 9 0}$ & 2890 & 9000 & $\mathbf{1 2 6 0}$ & $\mathbf{1 8 0 0}$ & 21.3 & 15.0 \\
\hline S_Sib & 2.9 & 2.9 & 18.2 & 30.1 & - & - & - & - & - & - \\
V_Alv & 8.1 & 20.0 & 371 & 382 & - & - & - & - & - & - \\
V_Sib & 22.7 & 29.7 & 182 & 275 & - & - & - & - & - & - \\
\hline
\end{tabular}

Table 3. Supplementary physico-chemical factors measured for some assemblages: $\mathrm{pH}$, methane flux $\left(\mathrm{F}\left(\mathrm{CH}_{4}\right)\right)$, total dissolved iron $(\mathrm{TdFe})$, total dissolved manganese ( $\mathrm{TdMn})$ and total dissolved copper $(\mathrm{TdCu})$. Due to sampling limitations, these factors were not available for all assemblages. Standard deviations are given in parentheses and the highest values per factor are shown in bold.

\begin{tabular}{lrrrrr}
\hline Abbreviation & $\mathrm{pH}$ & $\begin{array}{r}\mathrm{F}\left(\mathrm{CH}_{4}\right) \\
\left(\mathrm{mol} \mathrm{m}^{-2} \mathrm{~d}^{-1}\right)\end{array}$ & $\begin{array}{r}\mathrm{TdFe} \\
(\mu \mathrm{M})\end{array}$ & $\begin{array}{r}\mathrm{TdMn} \\
(\mu \mathrm{M})\end{array}$ & $\begin{array}{r}\mathrm{TdCu} \\
(\mathrm{nM})\end{array}$ \\
\hline G_ref & $7.5(0.06)$ & $-0.1(0.3)$ & $\mathrm{NA}$ & $\mathrm{NA}$ & $\mathrm{NA}$ \\
\hline S_VesP & $7.6(0.12)$ & $2.3(0.6)$ & $0.09(0.03)$ & 0.02 & $12.5(5.2)$ \\
S_VesA & $7.5(0.04)$ & $1.8(0.2)$ & $0.08(0.08)$ & $0.04(0.006)$ & $9.2(5.1)$ \\
S_Mat & $\mathbf{7 . 7}(0.10)$ & $\mathrm{NA}$ & $0.12(0.19)$ & $0.06(0.07)$ & $8.0(5.6)$ \\
S_Sib & $7.6(0.04)$ & $\mathrm{NA}$ & $0.14(0.11)$ & $0.16(0.005)$ & $9.4(7.8)$ \\
Mean seep & $7.6(0.10)$ & - & $0.10(0.10)$ & $0.07(0.07)$ & $9.6(5.8)$ \\
\hline V_VesA & $7.4(0.05)$ & $\mathbf{8 . 5}(0.7)$ & $0.06(0.03)$ & $0.06(0.04)$ & $\mathbf{2 1 . 6}(28.1)$ \\
V_Mat & $\mathrm{NA}$ & $\mathrm{NA}$ & $\mathrm{NA}$ & $\mathrm{NA}$ & $\mathrm{NA}$ \\
V_Alv & $6.9(0.13)$ & $\mathrm{NA}$ & $\mathbf{0 . 1 6}(0.002)$ & $0.46(0.10)$ & $11.5(6.4)$ \\
V_Sib & $7.0(0.13)$ & $\mathrm{NA}$ & $0.15(0.06)$ & $\mathbf{1 . 4 1}(0.50)$ & $2.5(0.9)$ \\
Mean vent & $7.2(0.26)$ & - & $0.10(0.06)$ & $0.40(0.60)$ & $15.7(23.1)$ \\
\hline
\end{tabular}

\section{Soft-sediment assemblages}

In soft-sediment assemblages, hydrogen sulfide, sulfates and ammonium concentrations were also compared (Table 2). Again, interface and maximum values were always correlated $(R>0.7, p<0.05)$. Thus, only maximal values are presented herein.

As expected, hydrogen sulfide concentrations were positively correlated with methane concentrations $(R>0.8$, $p<0.01$ ), whereas sulfate concentrations were negatively correlated with both hydrogen sulfide and methane concentrations $(R>0.7, p<0.05)$. Hydrogen sulfide was not detected at $G$ _ref. At seeps, maximum hydrogen sulfide concentrations ranged from undetected to $\sim 30000 \mu \mathrm{M}$. At vents, maximum hydrogen sulfide concentrations in the two softsediment assemblages ranged from $\sim 1700$ to $\sim 9000 \mu \mathrm{M}$.
Maximum ammonium concentrations were positively correlated to temperature, being higher at vents than seeps $(R>0.8, p<0.05)$.

Overall, regardless of the ecosystem, assemblages were related to two habitat groups according to the concentrations of reduced compounds, with higher fluid inputs at five assemblages (seeps: S_Gast and S_Mat, vents: V_Sib, V_Alv and V_Mat) against lower fluid inputs at five assemblages (seeps: S_Sib, S_SibP, S_VesA and S_VesP, vent: V_VesA). Despite some variations, seep and vent microbial mat (S_Mat, V_Mat) and vesicomyid (S_VesA, S_VesP, V_VesA) assemblages belonged to the same respective habitat groups, whereas seep and vent siboglinid (S_Sib and V_Sib) habitats differed strongly. Seep siboglinid habitat was characterised by lower fluid input than the vent siboglinid.

Although methane and hydrogen sulfide showed comparable concentration ranges among seep and vent ecosystems, 
temperature anomalies and ammonium concentrations were specific to vents. In addition, other compounds not available at all assemblages suggest further differences between seeps and vents. For example, the patterns of $\mathrm{pH}$ and manganese concentrations distinguished vents from seeps (Table 3). Mean Mn concentrations were significantly higher at vents than at seeps (Kruskal-Wallis test, $p<0.05$ ), while mean $\mathrm{pH}$ was significantly lower at vents (Kruskal-Wallis test, $p<0.05)$. These differences reflect the specific input of hydrothermal fluid in vent assemblages.

\subsubsection{Microbial populations with respect to the physicochemical conditions}

Microbial populations potentially involved in AOM processes co-varied with physicochemical conditions in the CIA performed on soft-sediment assemblages (Fig. 3, Table 4). The relationships were statistically significant $(p=0.01)$. According to the first axis, which contributed to $85 \%$ of the variance, high methane and hydrogen sulfide concentrations and low sulfate concentrations were associated with high abundances of ANMEs 1 and 2 at one end, corresponding to S_Mat, V_Mat and S_Gast assemblages. The second axis, which accounted for $15 \%$ of the variance, was driven by temperature anomalies and high $\mathrm{NH}_{4}$ concentrations at V_Mat, where a higher frequency of ANME 1 and a lower frequency of ANME 2 and DSS were found compared with S_Mat and S_Gast. The first CIA axis thus summarised the variance due to chemosynthetic processes and can be considered a proxy for fluid input across vent and seep ecosystems, whereas the second axis of the CIA summarised environmental conditions that are specific to vents.

\subsubsection{Foundation species descriptors}

At seeps, E. spicata and L. barhami siboglinids showed maximum size $(368 \mathrm{~mm})$ and biomass $\left(457 \mathrm{~g} \mathrm{~m}^{-2}\right)$, while the highest density was related to the small Hyalogyrina sp. gastropods (10 200 individuals per square metre $\left(\right.$ ind $^{-2}$ ); Table 5). At vents, $R$. pachyptila siboglinids had the maximum size $(431 \mathrm{~mm})$, biomass $\left(6630 \mathrm{~g} \mathrm{~m}^{-2}\right)$ and density (1280 ind $\mathrm{m}^{-2}$ ). Siboglinid width, density and biomass were much higher at vents than at seeps, while among the three vesicomyid assemblages, size, density and biomass were not statistically different.

\subsection{Macrofaunal community structure}

\subsubsection{Density patterns}

At seeps, macrofaunal densities ranged from 880 ind $\mathrm{m}^{-2}$ in S_Mat to $\sim 25000 \mathrm{ind}^{-2}$ in S_Gast (Table 6). At vents, densities ranged from $710 \mathrm{ind}^{-2}$ in $\mathrm{V}_{-}$Mat to 94400 ind $^{-2}$ in V_Sib. The density at $G \_$ref was the lowest with 570 ind $^{-2}$. Densities at the Guaymas reference, the seep assemblages and vent assemblages were significantly

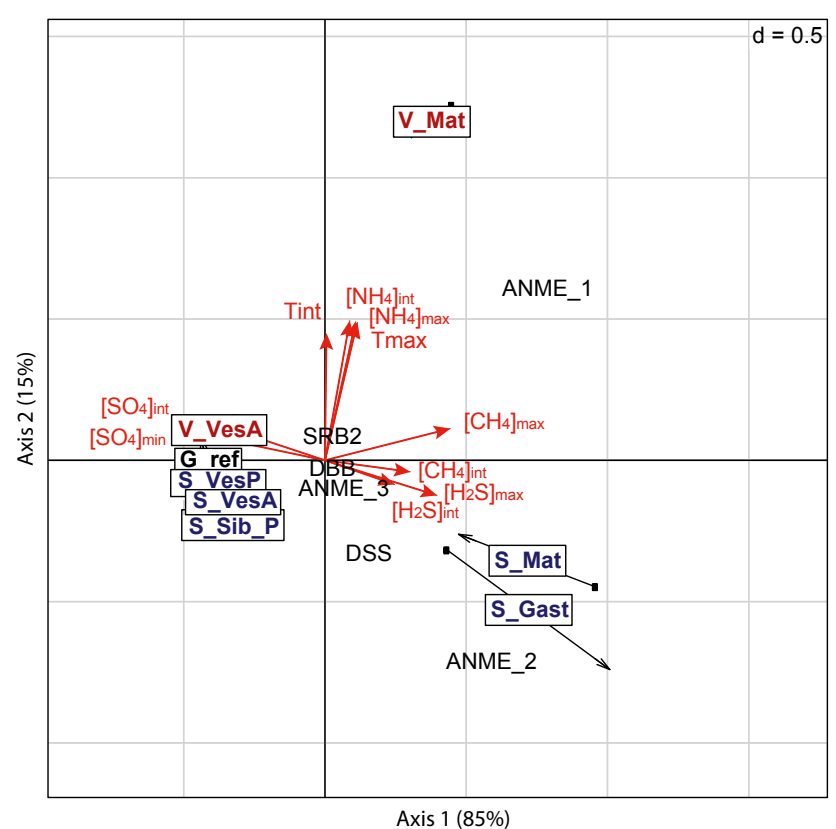

Figure 3. Co-inertia analysis of physicochemical factors in softsediment assemblages: temperature, methane $\left(\mathrm{CH}_{4}\right)$, hydrogen sulfide $\left(\mathrm{H}_{2} \mathrm{~S}\right)$, sulfate $\left(\mathrm{SO}_{4}\right)$, ammonium $\left(\mathrm{NH}_{4}\right)$ and relative abundances of microbial groups potentially involved in AOM: ANME1, ANME2, ANME3, DSS, DBB, SRB2. $p=0.01$, axis 1 accounts for $85 \%$ of the variation and axis 2 represents $15 \%$.

different $(p=0.03)$. Significant differences were found between reference and seep densities $(p<0.05)$, whereas at vents, density was not significantly different either from seeps, or from the reference. Relatively comparable density ranges were observed across ecosystems for microbial mats and vesicomyid assemblages, whereas those of siboglinid assemblages differed strongly, being higher at vents. Among the three vesicomyid assemblages, density differences were close to being significant ( $p=0.07)$. Significant differences were found with higher densities at the seep A. gigas assemblage (S_VesA) compared with the vent A. gigas (V_VesA) and seep $P$. soyoae $\left(\mathrm{S}_{-}\right.$VesP) assemblages $(p<0.05)$, with the latter assemblages showing comparable densities.

Macrofaunal densities did not show any significant correlation with physicochemical factors. However, logtransformed densities showed that, along the range of maximal methane concentrations, densities appeared to be enhanced at seep and vent vesicomyid assemblages and seep siboglinids and their periphery compared with the reference, whereas the highest methane concentrations at seep and vent microbial mats were related to the minimum densities observed over all chemosynthetic assemblages (Fig. 4). In between, high density fluctuations were found among vent alvinellid and vent siboglinid assemblages, despite relatively comparable maximal methane concentrations. A similar pattern was found between the seep gastropod assemblage and the seep and vent microbial mats. A polynomial relation- 
Table 4. Quantitative PCR results for six Archaea and Bacteria phyla potentially involved in the anaerobic oxidation of methane (AOM): ANME1, ANME2, ANME3, DSS, DBB and SRB2. Results are cumulated across the 0-10 cm sediment layer and expressed in 16S rRNA copy number per gram of sediment. The highest values for each group of AOM micro-organisms are shown in bold.

\begin{tabular}{lrrrrrr}
\hline Abbreviation & ANME1 & ANME2 & ANME3 & DSS & DBB & SRB2 \\
\hline G_ref & $8.16 \mathrm{E}+04$ & $1.40 \mathrm{E}+06$ & $2.74 \mathrm{E}+06$ & $1.10 \mathrm{E}+08$ & $4.08 \mathrm{E}+06$ & $5.42 \mathrm{E}+05$ \\
\hline S_VesP & $3.84 \mathrm{E}+07$ & $6.94 \mathrm{E}+07$ & $2.32 \mathrm{E}+05$ & $1.60 \mathrm{E}+08$ & $4.88 \mathrm{E}+06$ & $7.78 \mathrm{E}+06$ \\
S_VesA & $1.28 \mathrm{E}+08$ & $1.47 \mathrm{E}+08$ & $3.42 \mathrm{E}+06$ & $2.40 \mathrm{E}+08$ & $4.44 \mathrm{E}+06$ & $1.35 \mathrm{E}+06$ \\
S_Mat & $7.84 \mathrm{E}+08$ & $7.56 \mathrm{E}+08$ & $\mathbf{1 . 4 5 E}+\mathbf{0 8}$ & $\mathbf{4 . 7 2 E}+\mathbf{0 8}$ & $4.00 \mathrm{E}+07$ & $1.97 \mathrm{E}+07$ \\
S_Gast & $\mathbf{1 . 1 2 E}+\mathbf{0 9}$ & $\mathbf{1 . 4 7 E}+\mathbf{0 9}$ & $3.38 \mathrm{E}+07$ & $3.78 \mathrm{E}+08$ & $\mathbf{5 . 2 8 E}+\mathbf{0 7}$ & $1.15 \mathrm{E}+07$ \\
S_Sib_P & $5.10 \mathrm{E}+07$ & $2.62 \mathrm{E}+08$ & $1.65 \mathrm{E}+07$ & $2.18 \mathrm{E}+08$ & $3.62 \mathrm{E}+06$ & $2.16 \mathrm{E}+06$ \\
\hline V_VesA & $2.34 \mathrm{E}+05$ & $5.28 \mathrm{E}+05$ & $2.42 \mathrm{E}+06$ & $1.44 \mathrm{E}+08$ & $5.80 \mathrm{E}+06$ & $8.60 \mathrm{E}+05$ \\
V_Mat & $1.09 \mathrm{E}+09$ & $1.17 \mathrm{E}+08$ & $1.33 \mathrm{E}+06$ & $7.08 \mathrm{E}+07$ & $6.36 \mathrm{E}+06$ & $\mathbf{8 . 1 2 E}+\mathbf{0 7}$ \\
\hline
\end{tabular}

Table 5. Characteristics of foundation species (size, density and biomass) in the Guaymas Basin. Standard deviations are given in parentheses and highest values are shown in bold.

\begin{tabular}{|c|c|c|c|c|}
\hline & Species & $\begin{array}{r}\text { Length (L), diameter (D), } \\
\mathrm{mm}\end{array}$ & $\begin{array}{l}\text { Density } \\
\text { ind } \mathrm{m}^{-2}\end{array}$ & $\begin{array}{r}\text { Biomass } \\
\mathrm{g} \mathrm{m}^{-2}\end{array}$ \\
\hline \multicolumn{5}{|c|}{ Seep assemblages } \\
\hline S_Sib & E. spicata/L. barhami & L: 368 (116)/D: 6 (3) & 721 & 457 \\
\hline S_VesA & A. gigas & L: $75.0(8.9)$ & $102(42)$ & $262(119)$ \\
\hline S_VesP & P. soyoae & L: 87.1 (27.8) & $74.1(69.9)$ & $405(358)$ \\
\hline S_Gast & Hyalogyrina sp. & D: $2.0(0.3)$ & 10170 & 2.4 \\
\hline \multicolumn{5}{|c|}{ Vent assemblages } \\
\hline V_Sib & R. pachyptila & L: 431 (133)/D: 19.9 (9) & 1280 & 6630 \\
\hline V_VesA & A. gigas & L: $57.0(20.6)$ & $55.6(48.1)$ & $81.3(107)$ \\
\hline V_Alv & P. grasslei/P. bactericola & $\mathrm{L}: 24.2(14.4) / \mathrm{D}: 2.2(1.0)$ & 1070 & 31.2 \\
\hline
\end{tabular}

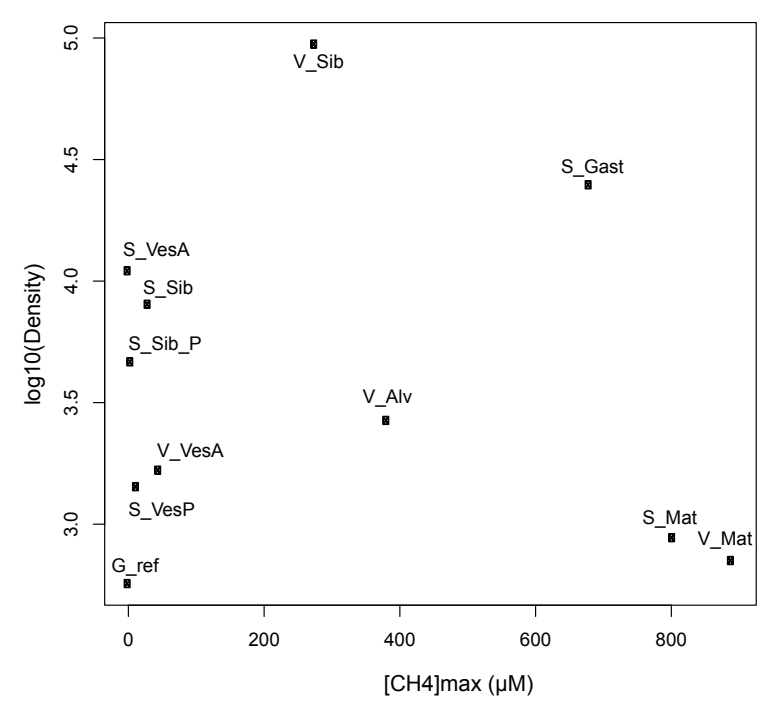

Figure 4. Log-transformed macrofaunal densities according to maximum methane concentrations in assemblages. ship between macrofaunal community density and foundation species density was found with S_Gast and V_Sib assemblages, harbouring higher densities of both foundation species and associated communities than the other assemblages $(R=0.8, p<0.05)$. No significant density differences were related to the nature of the substrata (soft versus hard substrata).

\subsubsection{Alpha diversity patterns}

As seen on rarefaction curves, the diversity was relatively well characterised depending on the assemblage. Four curves, corresponding to G_ref, V_VesA, V_Mat and S_Mat assemblages, did not reach an asymptote (Fig. 5), indicating insufficient sampling efforts. The sampling efforts at V_Mat and G_ref was indeed relatively lower than at assemblages where diversity was well characterised, but not at the V_VesA and S_Mat sites (Table 1).

ES(n) alpha diversity was estimated for each assemblage based on 41 individuals, corresponding to the minimum number of individuals observed at any one assemblage. $\mathrm{ES}_{41}$ at seeps ranged from 2 (S_Gast) to 13 families (S_Sib_P), 
Table 6. Macrofaunal community composition (expressed in terms of density: ind $\mathrm{m}^{-2}$ ) in the Guaymas Basin assemblages at the family level, including total densities (ind $\mathrm{m}^{-2}$ ) and $\mathrm{ES}_{41}$ diversity. Standard deviations are given in parentheses. The highest values for each assemblage are highlighted in bold.

\begin{tabular}{|c|c|c|c|c|c|c|c|c|c|c|c|c|c|c|c|c|c|c|c|c|c|c|c|c|c|c|}
\hline & \multicolumn{4}{|c|}{ G_ref } & \multicolumn{3}{|c|}{ S_VesP } & \multicolumn{3}{|c|}{ S_VesA } & \multicolumn{3}{|c|}{ S_Mat } & S_Gast & S_Sib & & S_S & ib_P & & & V_VesA & & V_N & & V_Alv & V_Sib \\
\hline & 1 & 2 & 3 & 4 & 1 & 2 & 3 & 1 & 2 & 3 & 1 & 2 & 3 & 1 & 1 & 1 & 2 & 3 & 4 & 1 & 2 & 3 & 1 & 2 & 1 & 1 \\
\hline Bivalvia & & & & & & & & & & & & & & & & & & & & & & & & & & \\
\hline Bathyspinulidae & 0 & 0 & 0 & 0 & 1778 & 361 & 83 & 1417 & 1583 & 972 & 333 & 28 & 111 & 0 & 144 & 556 & 167 & 333 & 111 & 167 & 222 & 417 & 0 & 0 & 0 & 0 \\
\hline Cuspidariidae & 0 & 0 & 0 & 0 & 0 & 0 & 0 & 28 & 0 & 0 & 0 & 0 & 0 & 0 & 0 & 0 & 0 & 56 & 56 & 0 & 0 & 0 & 0 & 0 & 0 & 0 \\
\hline Mytilidae & 0 & 0 & 0 & 0 & 0 & 0 & 0 & 0 & 0 & 0 & 0 & 0 & 0 & 0 & 86 & 0 & 0 & 0 & 0 & 0 & 0 & 0 & 0 & 0 & 0 & 71 \\
\hline Solemyidae & 0 & 0 & 0 & 0 & 28 & 56 & 0 & 0 & 28 & 0 & 0 & 0 & 0 & 0 & 0 & 0 & 0 & 0 & 0 & 0 & 28 & 0 & 0 & 0 & 0 & 0 \\
\hline Thyasiridae & 0 & 56 & 0 & 0 & 0 & 0 & 0 & 0 & 0 & 56 & 0 & 0 & 0 & 55.6 & 58 & 56 & 389 & 222 & 389 & 28 & 111 & 0 & 28 & 0 & 0 & 0 \\
\hline Gastropoda & & & & & & & & & & & & & & & & & & & & & & & & & & \\
\hline Aplustridae & 0 & 0 & 0 & 0 & 0 & 0 & 0 & 0 & 0 & 28 & 0 & 0 & 0 & 0 & 58 & 0 & 0 & 0 & 0 & 28 & 0 & 0 & 0 & 0 & 0 & 0 \\
\hline Cataegidae & 0 & 0 & 0 & 0 & 0 & 0 & 0 & 0 & 0 & 0 & 0 & 0 & 0 & 0 & 130 & 0 & 0 & 0 & 0 & 0 & 0 & 0 & 0 & 0 & 0 & 18 \\
\hline Hyalogyrinidae & 0 & 0 & 0 & 0 & 28 & 0 & 0 & 0 & 0 & 28 & 0 & 0 & 0 & 0 & 0 & 0 & 0 & 0 & 0 & 0 & 0 & 0 & 0 & 0 & 0 & 0 \\
\hline Lepetodrilidae & 0 & 0 & 0 & 0 & 0 & 0 & 0 & 0 & 0 & 0 & 0 & 0 & 0 & 0 & 2104 & 0 & 0 & 0 & 0 & 0 & 0 & 0 & 0 & 0 & 14 & 0 \\
\hline Neolepetopsidae & 0 & 0 & 0 & 0 & 56 & 83 & 111 & 28 & 56 & 0 & 0 & 0 & 0 & 0 & 735 & 0 & 0 & 0 & 0 & 0 & 0 & 0 & 0 & 0 & 0 & 0 \\
\hline Neomphaloidae & 0 & 0 & 0 & 0 & 0 & 0 & 0 & 0 & 56 & 0 & 0 & 0 & 0 & 0 & 0 & 0 & 0 & 0 & 0 & 0 & 250 & 28 & 0 & 0 & 0 & 0 \\
\hline Provannidae & 0 & 0 & 0 & 0 & 167 & 167 & 0 & 56 & 0 & 0 & 0 & 0 & 0 & 0 & 43 & 0 & 0 & 0 & 0 & 417 & 28 & 0 & 0 & 28 & 0 & 0 \\
\hline Pyramidellidae & 0 & 0 & 0 & 0 & 0 & 83 & 28 & 28 & 0 & 0 & 0 & 0 & 0 & 0 & 0 & 0 & 0 & 0 & 0 & 0 & 0 & 0 & 0 & 0 & 0 & 0 \\
\hline Pyropeltidae & 0 & 0 & 0 & 0 & 0 & 0 & 0 & 0 & 28 & 0 & 0 & 0 & 0 & 0 & 0 & 0 & 0 & 0 & 0 & 0 & 0 & 0 & 0 & 0 & 0 & 0 \\
\hline Polychaeta & & & & & & & & & & & & & & & & & & & & & & & & & & \\
\hline Acoetidae & 0 & 0 & 0 & 0 & 0 & 0 & 0 & 0 & 28 & 0 & 0 & 0 & 0 & 0 & 0 & 0 & 0 & 0 & 0 & 0 & 0 & 0 & 0 & 0 & 0 & 0 \\
\hline Ampharetidae & 0 & 167 & 0 & 56 & 0 & 0 & 0 & 556 & 1806 & 56 & 806 & 0 & 28 & 17222 & 0 & 0 & 0 & 0 & 0 & 167 & 28 & 194 & 139 & 83 & 86 & 8269 \\
\hline Amphinomidae & 0 & 0 & 0 & 0 & 0 & 0 & 0 & 28 & 0 & 0 & 0 & 0 & 0 & 0 & 0 & 0 & 0 & 0 & 0 & 0 & 0 & 0 & 0 & 0 & 0 & 0 \\
\hline Archinomidae & 0 & 0 & 0 & 0 & 0 & 0 & 0 & 0 & 0 & 0 & 0 & 0 & 0 & 0 & 87 & 0 & 0 & 0 & 0 & 0 & 0 & 0 & 0 & 0 & 0 & 0 \\
\hline Capitellidae & 0 & 0 & 56 & 0 & 56 & 0 & 0 & 0 & 83 & 0 & 0 & 0 & 0 & 0 & 0 & 111 & 0 & 0 & 0 & 0 & 0 & 0 & 0 & 0 & 0 & 0 \\
\hline Cirratulidae & 167 & 278 & 56 & 167 & 28 & 28 & 167 & 444 & 194 & 1056 & 28 & 0 & 0 & 0 & 29 & 944 & 167 & 944 & 1444 & 111 & 56 & 28 & 0 & 0 & 0 & 0 \\
\hline Cossuridae & 0 & 0 & 0 & 0 & 0 & 0 & 0 & 250 & 28 & 444 & 0 & 0 & 0 & 0 & 0 & 611 & 222 & 722 & 389 & 0 & 0 & 0 & 0 & 0 & 0 & 0 \\
\hline Dorvilleidae & 0 & 0 & 0 & 0 & 28 & 28 & 167 & 6472 & 3889 & 2750 & 361 & 472 & 194 & 7611 & 231 & 556 & 1944 & 556 & 167 & 500 & 1389 & 111 & 444 & 611 & 1543 & 85946 \\
\hline Flabelligeridae & 0 & 0 & 0 & 0 & 0 & 0 & 0 & 28 & 28 & 0 & 0 & 0 & 0 & 0 & 0 & 0 & 0 & 0 & 0 & 0 & 0 & 0 & 0 & 0 & 0 & 0 \\
\hline Glyceridae & 0 & 0 & 0 & 56 & 28 & 0 & 0 & 28 & 0 & 0 & 0 & 0 & 0 & 0 & 0 & 56 & 0 & 111 & 0 & 28 & 0 & 0 & 0 & 0 & 0 & 0 \\
\hline Goniadidae & 0 & 0 & 0 & 0 & 0 & 0 & 0 & 28 & 0 & 0 & 0 & 0 & 0 & 0 & 0 & 0 & 0 & 0 & 0 & 0 & 0 & 0 & 0 & 0 & 0 & 0 \\
\hline Hesionidae & 0 & 0 & 0 & 56 & 0 & 0 & 0 & 1278 & 583 & 167 & 111 & 0 & 28 & 0 & 0 & 444 & 444 & 111 & 111 & 83 & 0 & 0 & 28 & 0 & 0 & 0 \\
\hline Lacydonidae & 0 & 0 & 0 & 0 & 0 & 0 & 0 & 278 & 0 & 56 & 0 & 0 & 0 & 0 & 0 & 0 & 0 & 56 & 0 & 0 & 0 & 0 & 0 & 0 & 0 & 0 \\
\hline Lumbrineridae & 0 & 0 & 0 & 0 & 0 & 0 & 28 & 361 & 139 & 250 & 0 & 0 & 0 & 0 & 43 & 833 & 167 & 56 & 1000 & 28 & 0 & 0 & 0 & 0 & 0 & 0 \\
\hline Maldanidae & 0 & 0 & 0 & 0 & 28 & 0 & 56 & 56 & 56 & 28 & 0 & 0 & 0 & 0 & 43 & 56 & 0 & 0 & 0 & 0 & 0 & 0 & 0 & 0 & 0 & 0 \\
\hline Nautiliellidae & 0 & 0 & 0 & 0 & 0 & 56 & 0 & 0 & 28 & 0 & 0 & 0 & 0 & 0 & 0 & 0 & 0 & 0 & 0 & 0 & 0 & 0 & 0 & 0 & 0 & 0 \\
\hline Nephtyidae & 0 & 0 & 0 & 0 & 0 & 0 & 0 & 0 & 0 & 111 & 0 & 0 & 0 & 0 & 0 & 0 & 0 & 0 & 0 & 0 & 0 & 0 & 0 & 0 & 0 & 0 \\
\hline Nereididae & 56 & 222 & 0 & 0 & 0 & 0 & 0 & 83 & 194 & 28 & 0 & 0 & 0 & 0 & 259 & 0 & 0 & 0 & 0 & 28 & 0 & 0 & 56 & 0 & 0 & 0 \\
\hline Opheliidae & 0 & 0 & 0 & 0 & 0 & 0 & 0 & 0 & 0 & 0 & 0 & 0 & 0 & 0 & 0 & 0 & 0 & 0 & 56 & 0 & 0 & 0 & 0 & 0 & 0 & 0 \\
\hline Paraonidae & 167 & 56 & 56 & 0 & 0 & 0 & 0 & 167 & 0 & 222 & 0 & 0 & 0 & 0 & 0 & 444 & 389 & 444 & 333 & 0 & 0 & 0 & 0 & 0 & 0 & 0 \\
\hline Pholoidae & 0 & 56 & 0 & 0 & 0 & 0 & 0 & 28 & 0 & 28 & 0 & 0 & 0 & 0 & 0 & 0 & 0 & 56 & 0 & 0 & 0 & 0 & 0 & 0 & 0 & 0 \\
\hline Phyllodocidae & 0 & 0 & 0 & 0 & 0 & 0 & 0 & 0 & 0 & 0 & 0 & 0 & 0 & 0 & 332 & 0 & 0 & 0 & 0 & 0 & 0 & 0 & 0 & 0 & 0 & 0 \\
\hline Pilargidae & 0 & 0 & 111 & 0 & 0 & 0 & 0 & 56 & 0 & 83 & 0 & 0 & 0 & 0 & 0 & 0 & 0 & 0 & 167 & 0 & 28 & 0 & 0 & 0 & 0 & 0 \\
\hline Polynoidae & 0 & 0 & 0 & 0 & 0 & 0 & 0 & 28 & 0 & 83 & 28 & 0 & 0 & 0 & 1629 & 0 & 0 & 111 & 56 & 0 & 0 & 0 & 0 & 0 & 971 & 18 \\
\hline Serpulidae & 0 & 0 & 0 & 0 & 0 & 0 & 0 & 0 & 0 & 0 & 0 & 0 & 0 & 0 & 1485 & 0 & 0 & 0 & 0 & 0 & 0 & 0 & 0 & 0 & 0 & 0 \\
\hline Sigalionidae & 0 & 56 & 0 & 56 & 0 & 0 & 0 & 0 & 0 & 28 & 0 & 0 & 0 & 0 & 0 & 56 & 0 & 56 & 56 & 0 & 0 & 0 & 0 & 0 & 0 & 0 \\
\hline Sphaerodoridae & 0 & 0 & 0 & 0 & 0 & 0 & 0 & 139 & 83 & 83 & 0 & 0 & 0 & 0 & 14 & 0 & 0 & 0 & 0 & 28 & 0 & 0 & 0 & 0 & 0 & 0 \\
\hline Spionidae & 56 & 111 & 0 & 0 & 0 & 0 & 0 & 28 & 56 & 83 & 0 & 0 & 0 & 0 & 43 & 222 & 0 & 56 & 111 & 0 & 0 & 0 & 0 & 0 & 0 & 0 \\
\hline Sternaspidae & 0 & 0 & 0 & 0 & 0 & 0 & 0 & 28 & 0 & 28 & 0 & 0 & 0 & 0 & 0 & 0 & 0 & 0 & 0 & 0 & 0 & 28 & 0 & 0 & 0 & 0 \\
\hline Syllidae & 0 & 0 & 0 & 0 & 0 & 0 & 0 & 0 & 0 & 0 & 0 & 27 & 0 & 0 & 0 & 0 & 0 & 0 & 0 & 0 & 0 & 0 & 0 & 0 & 0 & 0 \\
\hline Terebellidae & 0 & 0 & 0 & 0 & 139 & 0 & 0 & 56 & 28 & 0 & 0 & 0 & 0 & 0 & 404 & 0 & 0 & 111 & 0 & 0 & 0 & 0 & 0 & 0 & 0 & 0 \\
\hline Trichobranchidae & 0 & 0 & 0 & 0 & 0 & 0 & 0 & 0 & 0 & 28 & 0 & 0 & 0 & 0 & 0 & 0 & 0 & 0 & 56 & 0 & 0 & 0 & 0 & 0 & 0 & 0 \\
\hline Others & & & & & & & & & & & & & & & & & & & & & & & & & & \\
\hline Actinaria & 0 & 56 & 0 & 0 & 0 & 56 & 0 & 83 & 0 & 0 & 0 & 0 & 0 & 0 & 0 & 0 & 56 & 0 & 0 & 0 & 0 & 0 & 0 & 0 & 0 & 0 \\
\hline Amphipoda & 0 & 0 & 0 & 0 & 0 & 0 & 0 & 0 & 56 & 28 & 0 & 0 & 0 & 0 & 29 & 56 & 0 & 0 & 0 & 333 & 28 & 0 & 0 & 0 & 0 & 26 \\
\hline Aplacophora & 0 & 0 & 56 & 56 & 0 & 0 & 56 & 1250 & 917 & 222 & 28 & 0 & 0 & 0 & 14 & 56 & 0 & 56 & 0 & 0 & 56 & 28 & 0 & 0 & 0 & 0 \\
\hline Cnidaria & 0 & 0 & 0 & 0 & 0 & 0 & 0 & 28 & 28 & 0 & 0 & 0 & 0 & 0 & 0 & 0 & & 0 & 0 & 0 & 0 & 0 & 0 & 0 & 0 & 0 \\
\hline Cumacea & 0 & 0 & 0 & 0 & 0 & 0 & 0 & 0 & 0 & 0 & 56 & 0 & 0 & 0 & 0 & 0 & 0 & 0 & 0 & 0 & 0 & 0 & 0 & 0 & 0 & 0 \\
\hline Nemertina & 0 & 0 & 0 & 0 & 0 & 0 & 0 & 194 & 389 & 56 & 0 & 0 & 0 & 0 & 0 & 0 & 167 & 0 & 0 & 0 & 0 & 0 & 0 & 0 & 0 & 0 \\
\hline Ophiuridae & 0 & 0 & 0 & 0 & 83 & 194 & 28 & 306 & 861 & 833 & 0 & 0 & 0 & 0 & 29 & 0 & 0 & 56 & 0 & 0 & 0 & 0 & 0 & 0 & 0 & 0 \\
\hline Scaphopoda & 0 & 0 & 0 & 0 & 0 & 0 & 0 & 0 & 0 & 0 & 0 & 0 & 0 & 0 & 0 & 111 & 0 & 0 & 0 & 0 & 0 & 0 & 0 & 0 & 0 & 0 \\
\hline Sipuncula & 0 & 0 & 0 & 0 & 0 & 0 & 0 & 167 & 28 & 0 & 0 & 0 & 0 & 0 & 0 & 0 & 0 & 0 & 0 & 0 & 0 & 0 & 0 & 0 & 0 & 0 \\
\hline Tanaidacea & 0 & 0 & 0 & 0 & 0 & 0 & 0 & 0 & 28 & 0 & 0 & 0 & 0 & 0 & 0 & 611 & 0 & 56 & 56 & 0 & 0 & 0 & 0 & 0 & 0 & 0 \\
\hline Mean density & & 569 & 328) & & & $26(903)$ & & & $037(309$ & & & $80(762)$ & & 24889 & 8028 & & 4653 & (776) & & & 667 (735) & & 708 & & 2614 & 94348 \\
\hline $\mathrm{ES}_{41}$ & & 1 & & & & 11.1 & & & 12.2 & & & 6.4 & & 2.1 & 10.9 & & 12 & & & & 10.3 & & 5. & & 3 & 2 \\
\hline
\end{tabular}

and from 2 (V_Sib) to 10 families (V_VesA) at vents, while the reference included 14 families (G_ref, Table 6).

Alpha diversity appeared maximal at the Guaymas reference (as observed with $\operatorname{ES}(\mathrm{n})$ and the rarefaction curve) and was not significantly different among seeps and vents. Relatively comparable $\mathrm{ES}_{41}$ values were observed in microbial mat and vesicomyid vent and seep assemblages, whereas they showed strong differences in siboglinid assemblages, with lower diversity at the vent one. Although $\mathrm{ES}_{41}$ did not separate the three vesicomyid assemblages, the rarefaction curves showed higher diversity in the seep A. gigas assemblage compared with the seep $P$. soyoae assemblage. The diversity in the vent $A$. gigas assemblage was not sufficiently characterised, but appeared to be intermediate between the two vesicomyid seep assemblages (Fig. 5).

A negative correlation was observed between $\mathrm{ES}_{41}$ and temperature anomalies $(R>0.6, p<0.05)$, reflecting that three of the four vent assemblages showed relatively low diversity, whereas four of the six seep assemblages had relatively high diversity. A strong negative correlation was 


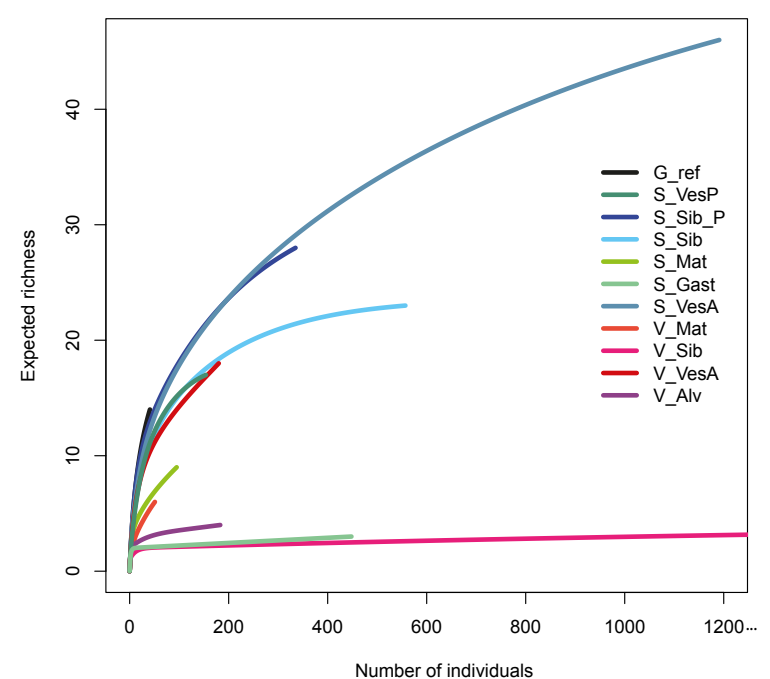

Figure 5. Rarefaction curves on pooled macrofaunal abundances from each assemblage.

found between $\mathrm{ES}_{41}$ and methane concentrations for all assemblages $(R>0.8, p<0.01)$. $\mathrm{ES}_{41}$ on soft-sediment assemblages was positively correlated with sulfate concentrations and negatively correlated with hydrogen sulfide and methane concentrations $(R>0.7, p<0.05)$. In addition, a linear regression model was fit to the relationship between $\mathrm{ES}_{41}$ and maximum methane concentrations, previously logtransformed, among all assemblages to compare our data with previous studies. This regression was highly significant $\left(R^{2}=0.78, p<0.001\right)$ and reflected a decrease in diversity along a fluid input gradient (Fig. 6).

\subsubsection{Community composition patterns}

Macrofaunal community composition varied both within and between ecosystems. The relative abundances of macrofaunal taxa within assemblages are presented in Fig. 7 and their inter-assemblage variability in Fig. 8.

All macrofaunal communities were dominated by Polychaeta at the reference $(90.2 \%$ ), at seeps (from 57.3 to $99.8 \%$ ), with the exception of S_VesP where Bivalvia dominated $(53.9 \%$ ) and at vents (from 56.7 to $99.9 \%$ ). At the family level, a strong inter-assemblage variability was observed. The three first axes of the between-group PCA, a particular case of RDA that tests and maximises the variance between assemblages, accounted for $51 \%$ of the total variance in community composition. The intra-assemblage heterogeneity was relatively high, but lower than the interassemblage variability, with the exception of S_VesA and V_VesA in which there was a slight overlap. The first axis of the PCA accounted for $27 \%$ of the variability in community composition, mostly separating the G_ref and S_Sib_P assemblages dominated by Cirratulidae, Paraonidae and Spionidae polychaetes from the V_Sib, V_Mat, V_Alv, S_Gast

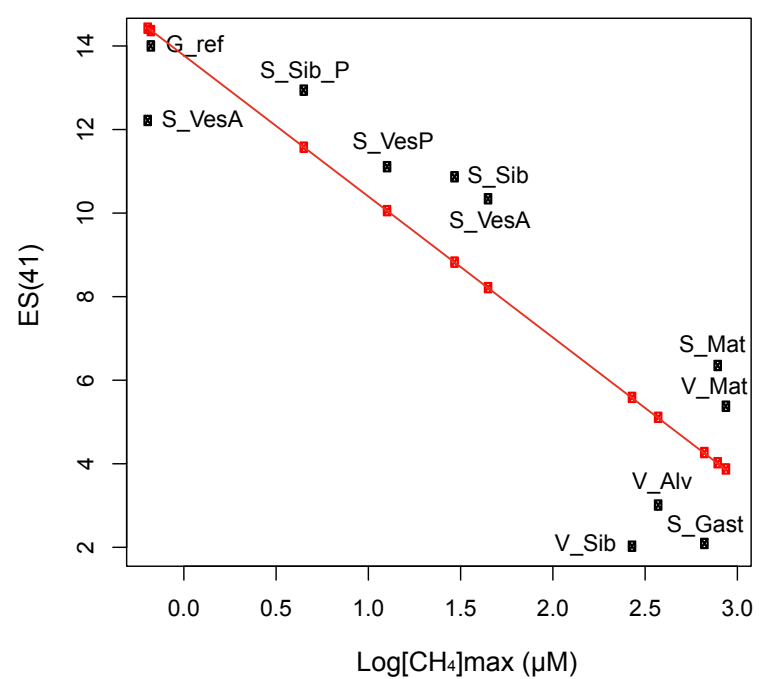

Figure 6. Logarithmic regression between species richness, ES(41), and maximum methane concentration in all macrofaunal assemblages. Black squares represent observed data points and red squares represent fitted values.

and S_Mat assemblages, characterised by higher frequencies of Dorvilleidae and Ampharetidae polychaetes. Intermediate compositions were found at S_Sib_P, S_VesP, S_VesA and V_VesA. The second axis accounted for $14 \%$ of the variance in macrofaunal community composition. It was mainly influenced by the dominance of the Bathyspinulidae bivalves at S_VesP. The third axis accounted for $10 \%$ of the variance, differentiating in particular the S_Sib assemblage, characterised by the presence of Polynoidae, Lepetodrilidae, Neolepetopsidae, Serpulidae and Nereididae.

Overall, although the heterogeneity between macrofaunal communities appeared higher at seeps than at vents, there was no differentiation between vent and seep assemblages. Community compositions across seep and vent common microbial mats and vesicomyid assemblages were closely related, whereas they differed according to the ecosystem they belonged to among siboglinid assemblages. Of the three vesicomyid assemblages, those dominated by A. gigas at seeps and vents were more similar than those dominated by $P$. soyoae in seeps.

\section{Relationships with site characteristics}

The forward selection test showed that the variation of macrofaunal community composition among assemblages was significantly influenced by maximum methane concentrations and the type of substratum $(p<0.01)$, whereas temperature anomalies and the biomass and density of foundation species were not significant. The first two components of the canonical redundancy analysis (RDA) accounted for respectively $27 \%(p=0.01)$ and $13 \%(p=0.08)$ of the variability in macrofaunal composition (adjusted $R^{2}$, 


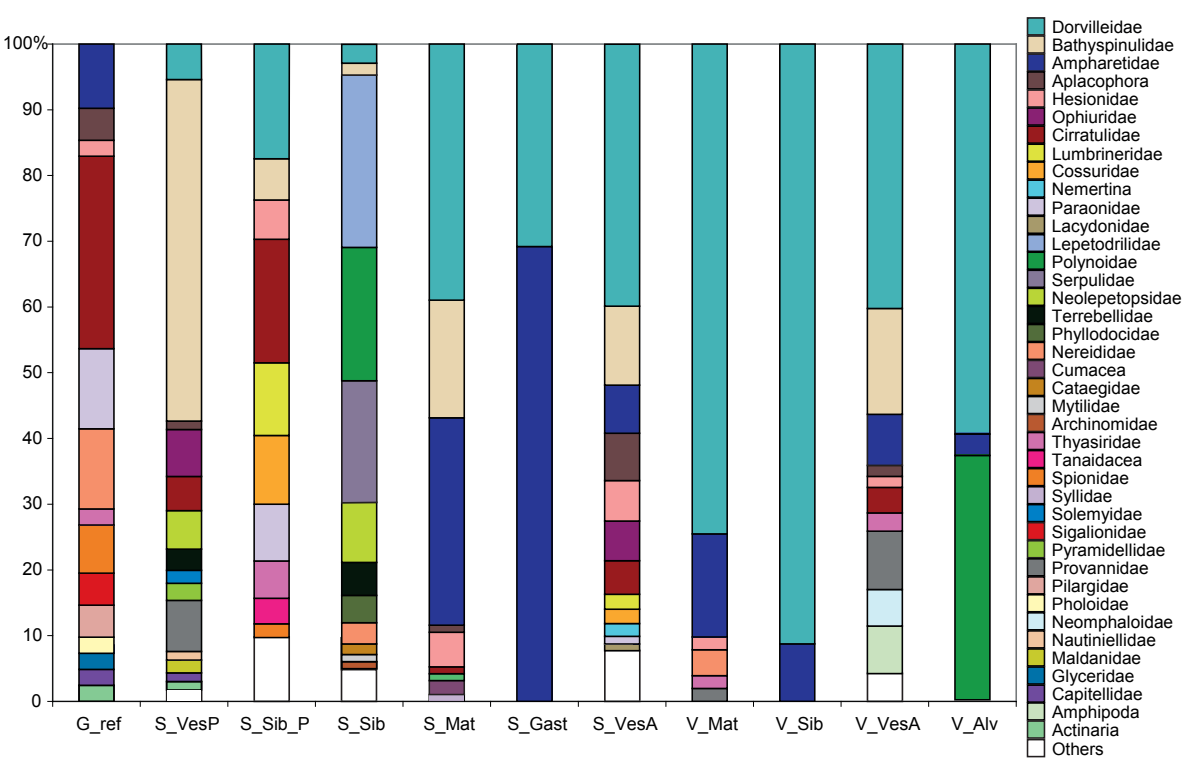

Figure 7. Histograms of relative macrofaunal compositions at the family level in assemblages shown for each study site; only taxa contributing to more than $1 \%$ are shown.
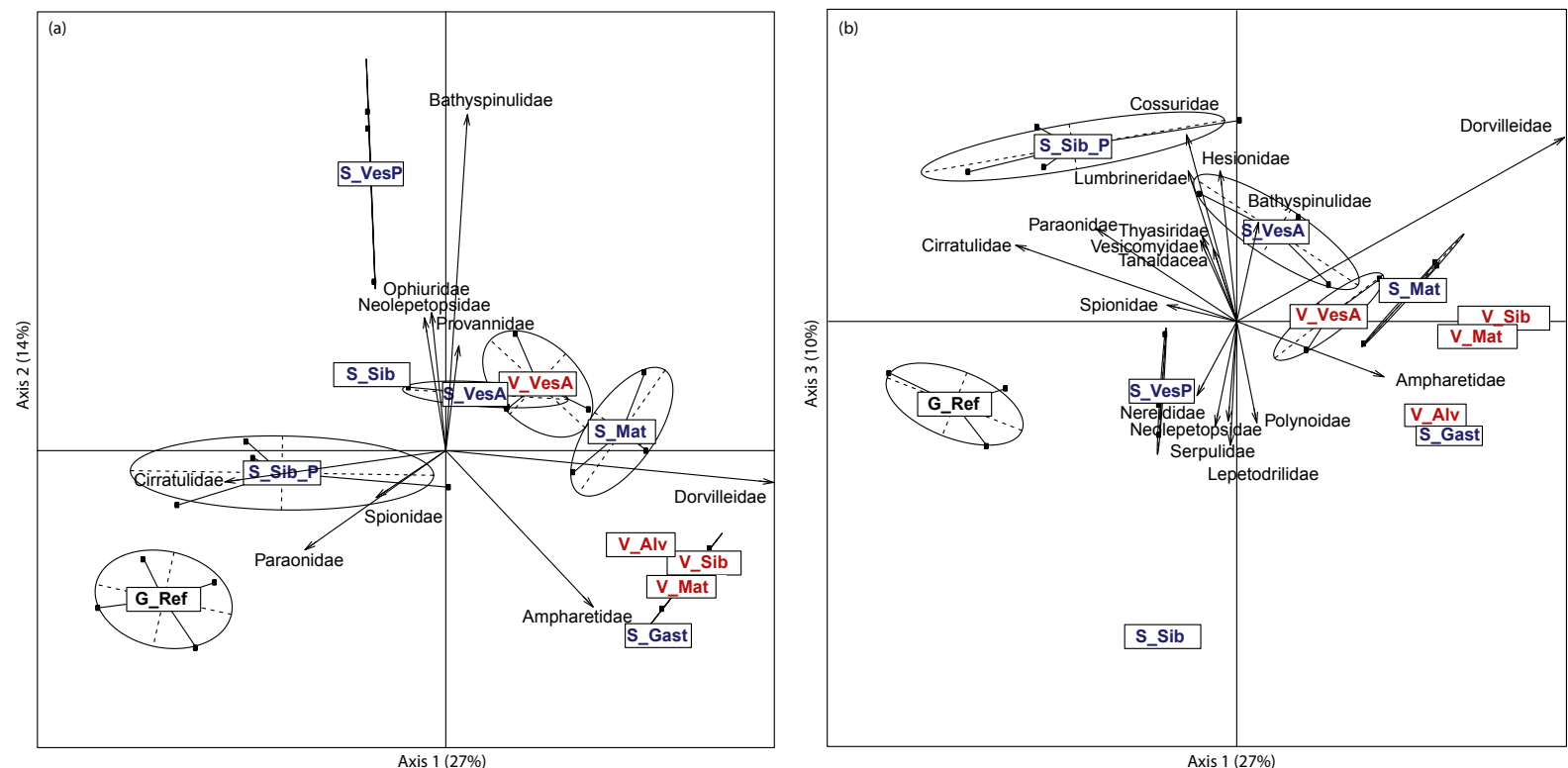

Figure 8. Between-group principal component analysis (PCA) on Hellinger-transformed macrofaunal densities of the 26 sampling units studied in the Guaymas Basin. (a) The axis 1 accounts for $27 \%$ of the variance in the macrofaunal data and axis 2 accounts for $14 \%$. (b) The axis 1 accounts for $27 \%$ of the variance in the macrofaunal data and axis 3 accounts for $10 \%$. Only taxa contributing to more than $2 \%$ to an axis are shown.

0.25; Fig. 9). The first axis was mostly driven by maximum methane concentrations. The high methane concentrations at the S_Gast, V_Sib, V_Mat, V_Alv and S_Mat habitats were mainly associated with the dominance of dorvilleids and ampharetids and to a lesser extent to polynoids. The low methane concentrations at all other habitats were linked to higher abundances of cirratulids, bathyspinulids, paranoids, lumbrinerids, aplacophorans, ophiurids, hesionids and neolepetopsids. Nevertheless, in this latter group, S_VesA and V_VesA compositions had more affinities with assemblages characterised by high methane concentrations. The second RDA axis was driven by the type of substratum (hard/soft) but also by higher methane concentrations in V_Mat, S_Mat and S_Gast habitats. At one axis end, hard substrata mainly 

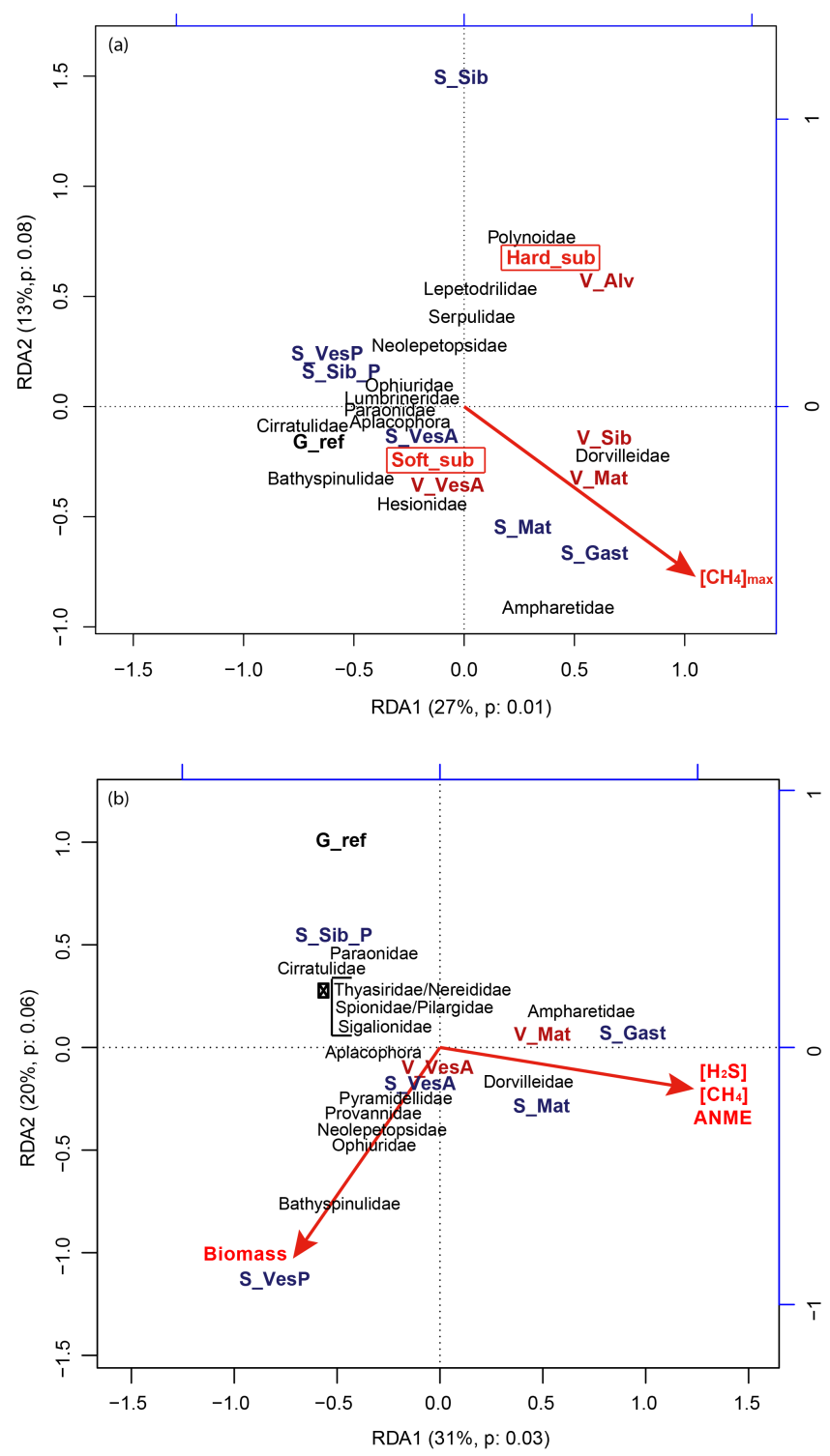

Figure 9. Canonical redundancy analysis (RDA, scaling type 1) of Hellinger-transformed macrofaunal densities as a function of qualitative and normalised quantitative environmental conditions for all assemblages (a) or for soft-sediment assemblages (b). Only significant explanatory variables are shown (a) methane concentration and substratum type; (b) first axis of the prior co-inertia analysis and engineer species biomass). Only the names of the taxa that showed good fit with the first two canonical axes (fitted value $>0.20$ ) are shown on the plots.

contributed to S_Sib and V_Alv macrofaunal composition, with the presence of polynoids at $\mathrm{V} \_$Alv coupled to that of lepetodrilids, serpulids and neolepetopsids at $S_{-}$Sib. At the other axis end, the higher methane concentrations in V_Mat, S_Mat and S_Gast mainly accounted for the higher dominance of ampharetids whereas soft substrata appeared to explain the abundance of hesionids and bathyspinulids.
Focusing on soft-sediment assemblages, the forward selection test showed that macrofaunal community composition was significantly influenced by the first axis of the coinertia analysis (CIA) and the biomass of foundation species, which were the best explanatory variables ( $p$ values of 0.01 and 0.07 , respectively). The relationship with the first axis of the CIA, which we interpreted as a proxy for fluid input across ecosystems, was highly significant, whereas the relationship with the second axis of the CIA, which we interpreted as being vent-specific, was not. The first two components of the RDA accounted for respectively $31 \%$ $(p=0.03)$ and $20 \%(p=0.06)$ of the variability in macrofaunal composition (adjusted $R^{2}=0.31$; Fig. 9). According to the first axis, higher fluid inputs at S_Mat, V_Mat, S_Gast contributed to the high dominance of ampharetids and dorvilleids. At the other end, all other assemblages were characterised by a higher proportion of taxa from the Cirratulidae and Bathyspinulidae families. In this latter group, S_VesA, V_VesA assemblages were found to have more affinities with assemblages of high fluid input than the other assemblages. The second axis was mainly driven by the biomass of foundation species, distinguishing $\mathrm{S}_{-}$VesP from the other assemblages with high frequencies of nuculanid bivalves, ophiurids, and gastropods compared with lower frequencies dominance of several polychaete families. This pattern may also be related to differences in the engineering effects of $P$. soyoae at S_VesP, compared to A. gigas, at S_VesA and V_VesA.

\subsubsection{Faunal composition similarity between seep and vent ecosystems}

At the family level, the gamma diversity of macrofaunal communities reached 56 families at the seep ecosystem, 22 families at vent ecosystem and 14 at the reference. All the families found at the reference were also found at the seep and eight of them were shared with the vent. As the diversity at the reference was estimated from only one assemblage, its faunal similarity/dissimilarity to seep and vent ecosystems was not quantified. Between seep and vent macrofaunal composition, the Sorensen dissimilarity was estimated at $42 \%$ and corresponded only to nestedness (species loss), whereas the dissimilarity linked to turnover (species replacement) was null. All the 22 families found at vent were also found at seep with seep exhibiting 28 specific families and 6 families only shared with the reference.

In all, 26 species belonging to 18 seep and vent dominant families were identified (Table 7). Of these, the vast majority (22 species) were found in both ecosystems, whereas only two species of gastropods were specific to seep (Eulimella lomana and Paralepetopsis sp.) and two were restricted to vent (the polynoid Branchiplicatus cupreus and the gastropod Pyropelta musaica). 
Table 7. Presence or absence of seep and vent species in the Guaymas Basin (*: species not found within our study but previously recorded in Guaymas vents) and species records from other studies in the Costa Rica "hydrothermal seep" (CRHS) and, more generally, at cold seeps (CS), vents (HV) or organic falls (OF) around the world.

\begin{tabular}{|c|c|c|c|c|c|c|c|}
\hline & $\begin{array}{r}\text { Guaymas } \\
\text { Seep }\end{array}$ & $\begin{array}{r}\text { Guaymas } \\
\text { Vent }\end{array}$ & CRHS & CS & HV & $\mathrm{OF}$ & References \\
\hline \multicolumn{8}{|c|}{ Foundation species } \\
\hline Phreagena soyoae & $\mathrm{x}$ & $\mathrm{x}^{*}$ & & $\mathrm{x}$ & $\mathrm{x}$ & $\mathrm{x}$ & Baco et al. (1999); Audzijonyte et al. (2012) \\
\hline Archivesica gigas & $\mathrm{x}$ & $\mathrm{x}$ & $\mathrm{x}$ & $\mathrm{x}$ & $\mathrm{x}$ & $\mathrm{x}$ & $\begin{array}{l}\text { Krylova and Sahling (2010); Audzijonyte et al. (2012); Smith et } \\
\text { al. (2014); Levin et al. (2012a) }\end{array}$ \\
\hline Calyptogena pacifica & $\mathrm{x}$ & & & $\mathrm{x}$ & $\mathrm{x}$ & $\mathrm{x}$ & Huber (2010); Audzijonyte et al. (2012); Smith et al. (2014) \\
\hline Paralvinella bactericola & & $\mathrm{x}$ & & & & & Desbruyères and Laubier (1991) \\
\hline Paralvinella grasslei & & $\mathrm{x}$ & & & $\mathrm{x}$ & & Desbruyères and Laubier (1982); Zal et al. (1995) \\
\hline Riftia pachyptila & & $\mathrm{x}$ & & & $\mathrm{x}$ & & Black et al. (1994) \\
\hline Escarpia spicata & $\mathrm{x}$ & $x^{*}$ & $\mathrm{x}$ & $\mathrm{x}$ & & $\mathrm{x}$ & $\begin{array}{l}\text { Black et al. (1997); Levin et al. (2012a); Feldman et al. (1998); } \\
\text { Tunnicliffe (1991) }\end{array}$ \\
\hline Lamellibrachia barhami & $\mathrm{x}$ & & $\mathrm{x}$ & $\mathrm{x}$ & $\mathrm{x}$ & & Black et al. (1997); Levin et al. (2012a) \\
\hline Hyalogyrina sp. & $\mathrm{x}$ & & genus & genus & genus & genus & $\begin{array}{l}\text { Smith and Baco (2003); Bernardino et al. (2010); Smith et al. (2014); } \\
\text { Sahling et al. (2002); Sasaki et al. (2010); Levin et al. (2012a) }\end{array}$ \\
\hline \multicolumn{8}{|c|}{ Associated macrofauna } \\
\hline Nuculana grasslei & $\mathrm{x}$ & $\mathrm{x}$ & & & & & Allen (1993) \\
\hline Acharax aff. johnsoni & $\mathrm{x}$ & $\mathrm{x}$ & & $\mathrm{x}$ & & & Kamenev (2009) \\
\hline Sirsoe grasslei & $\mathrm{x}$ & $\mathrm{x}$ & & & & & Blake and Hilbig (1990) \\
\hline Ophryotrocha platykephale & $\mathrm{x}$ & $\mathrm{x}$ & & $\mathrm{x}$ & & $\mathrm{x}$ & Weiss and Hilbig (1992); Levin et al. (2003); Smith et al. (2014) \\
\hline Ophryotrocha akessoni & $\mathrm{x}$ & $\mathrm{x}$ & & & $\mathrm{x}$ & & Blake and Hilbig (1990) \\
\hline Parougia sp. & $\mathrm{x}$ & $\mathrm{x}$ & & genus & genus & genus & $\begin{array}{l}\text { Smith and Baco (2003); Bernardino et al. (2010); Levin et al. (2003); } \\
\text { Levin (2005); Smith et al. (2014) }\end{array}$ \\
\hline Exallopus jumarsi & $\mathrm{x}$ & $\mathrm{x}$ & & & & & Petrecca and Grassle (1990) \\
\hline Branchinotogluma sandersi & $\mathrm{x}$ & $\mathrm{x}$ & & & $\mathrm{x}$ & & Blake and Hilbig (1990) \\
\hline Branchinotogluma hessleri & $\mathrm{x}$ & $\mathrm{x}$ & & & $\mathrm{x}$ & & Blake and Hilbig (1990) \\
\hline Bathykurila guaymasensis & $\mathrm{x}$ & $\mathrm{x}$ & & & & $\mathrm{x}$ & $\begin{array}{l}\text { Pettibone (1993); Smith and Baco (2003); Blake and Hilbig (1990); } \\
\text { Blake (1990); Smith (2003) }\end{array}$ \\
\hline Branchiplicatus cupreus & & $\mathrm{x}$ & & & $\mathrm{x}$ & & Blake and Hilbig (1990) \\
\hline Nereis sandersi & $\mathrm{x}$ & $\mathrm{x}$ & & & $\mathrm{x}$ & & Blake and Hilbig (1990) \\
\hline Nicomache venticola & $\mathrm{x}$ & $\mathrm{x}$ & & & $\mathrm{x}$ & & Blake and Hilbig (1990) \\
\hline Aphelochaeta sp. & $\mathrm{x}$ & $\mathrm{x}$ & & genus & & & Levin et al. (2003) \\
\hline Sigambra sp. & $\mathrm{x}$ & $\mathrm{x}$ & & genus & & $\mathrm{x}$ & Levin and Mendoza (2007); Dahlgren et al. (2004) \\
\hline Amphisamytha aff. fauchaldi & $\mathrm{x}$ & $\mathrm{x}$ & $\mathrm{x}$ & $\mathrm{x}$ & & & Stiller et al. (2013) \\
\hline Parvaplustrum sp. & $\mathrm{x}$ & $\mathrm{x}$ & & & & & \\
\hline Provanna sp. (spiny) & $\mathrm{x}$ & $\mathrm{x}$ & $\mathrm{x}$ & & & & Levin et al. (2012a) \\
\hline Provanna laevis & $\mathrm{x}$ & $\mathrm{x}$ & $\mathrm{x}$ & $\mathrm{x}$ & & & $\begin{array}{l}\text { Sahling et al. (2002); Sasaki et al. (2010); Smith and Baco (2003); } \\
\text { Levin and Sibuet (2012); Levin et al. (2012a); Warén and } \\
\text { Bouchet (1993) }\end{array}$ \\
\hline Retiskenea diploura & $\mathrm{x}$ & $\mathrm{x}$ & & $\mathrm{x}$ & & & Sahling et al (2002); Sasaki et al. (2010) \\
\hline Eulimella lomana & $\mathrm{x}$ & $x^{*}$ & $\mathrm{x}$ & $\mathrm{x}$ & & $\mathrm{x}$ & $\begin{array}{l}\text { Sahling et al. (2002); Sasaki et al. (2010); Smith and Baco (2003); } \\
\text { Levin and Sibuet (2012); Levin et al. (2012a); Warén and } \\
\text { Bouchet (1993) }\end{array}$ \\
\hline Lepetodrilus guaymasensis & $\mathrm{x}$ & $\mathrm{x}$ & $\mathrm{x}$ & & & & Levin et al. (2012a); Sasaki et al. (2010) \\
\hline Pyropelta corymba & $\mathrm{x}$ & $\mathrm{x}$ & $\mathrm{x}$ & $\mathrm{x}$ & & $\mathrm{x}$ & Sasaki et al. (2010); Levin et al. (2012a); Smith and Baco (2003) \\
\hline Pyropelta musaica & & $\mathrm{x}$ & & $\mathrm{x}$ & $\mathrm{x}$ & $\mathrm{x}$ & Smith and Baco (2003); Tunnicliffe (1991); Sasaki et al (2010) \\
\hline Paralepetopsis sp. & $\mathrm{x}$ & & & genus & genus & genus & Sasaki et al. (2010) \\
\hline Cataegis sp. & $\mathrm{x}$ & $\mathrm{x}$ & genus & genus & & & Levin et al. (2012a;) Sasaki et al. (2010) \\
\hline
\end{tabular}

\section{Discussion}

Previous comparative studies have highlighted strong differences between seep and vent macrofaunal communities (Bernardino et al., 2012; Tunnicliffe et al., 2003, 1998; Sibuet and Olu, 1998; Turnipseed et al., 2003 2004; Watanabe et al., 2010; Nakajima et al., 2014). However, to date, large-scale ecological factors and biogeographic barriers have limited any direct comparisons of the impact of seep- and vent-specific environmental conditions. Although methane and hydrogen sulfide appear to be potential common structuring factors across seep and vent ecosystems, ecosystem-specific fluid properties may further shape community patterns. In addition, other environmental factors such as the type of substratum and the role of foundation species as engineers could potentially add complexity within communities (Govenar, 2010; Cordes et al., 2010).

\subsection{Similarities and differences in site biogeochemistry}

\section{Substratum}

Both Guaymas chemosynthetic ecosystems showed typical faunal assemblages colonising hard (seep: siboglinid, vent: 
siboglinid, alvinellid) and soft substrata (seep: vesicomyid, gastropod and microbial mat, vent: vesicomyid and microbial mat). The nature of hard substratum differed among ecosystems with authigenic carbonates at seeps (Paull et al., 2007) and sulfide edifices at vents (Jørgensen et al., 1990).

\section{Vent and seep physicochemical conditions}

Methane and hydrogen sulfide used as fluid input proxies had similar concentration ranges in seep and vent ecosystems. Seep and vent assemblages were divided in two groups, regardless of the ecosystem: those with low fluid inputs (seep siboglinid and periphery and seep and vent vesicomyid assemblages) and those with high fluid inputs (seep and vent microbial mat, seep gastropod, vent siboglinid and vent alvinellid assemblages). In addition, two of the three seep and vent common assemblages (vesicomyid and microbial mat) showed relatively comparable fluid inputs. Microbial mat assemblages are indeed usually characterised by strong fluid inputs, whereas vesicomyid habitats are related to lower fluid inputs (Levin, 2005). The third common assemblage did not exhibit the same pattern: the vent siboglinid habitat was associated with much higher fluid inputs than seep habitat. Siboglinid species at seeps and vents tend to occupy different ecological niches along a gradient of fluid flux. The seep $L$. barhami and E. spicata siboglinids pump hydrogen sulfide through their roots deep in the sediment in low-flux settings (Julian et al., 1999) and the vent taxon R. pachyptila captures the chemical elements through its gills, in stronger fluid flux conditions (Arp and Childress, 1983).

In sediment-covered vent fields, fluid emissions at the water-substratum interface may differ strongly from the original end-member fluids and potentially lead to reduced seep and vent environmental discrepancies, as shown elsewhere in terms of temperature and geochemistry (Sahling et al., 2005; Tunnicliffe et al., 2003; LaBonte et al., 2007; Von Damm et al., 1985). Although the Guaymas seep and vent habitats shared comparable ranges of methane and hydrogen sulfide concentrations, vents showed temperature anomalies correlated to the fluid inputs, ranging from $6.5^{\circ} \mathrm{C}$ in the vesicomyid assemblage to $55.5^{\circ} \mathrm{C}$ in the microbial mat. Vents were also characterised by higher ammonium concentrations, lower $\mathrm{pH}$ and higher manganese concentrations than seeps, reflecting the end-member concentration of the vent fluids (Von Damm et al., 1985). Vent enrichment in ammonium is related to the thermocatalytic percolation of sedimentary organic matter by hydrothermal fluids, a process that produces methane and petroleum-like aliphatic and aromatic hydrocarbons (Bazylinski et al., 1988; Von Damm et al., 1985; Pearson et al., 2005; Simoneit et al., 1992).

Vent-specific factors such as temperature, metals, $\mathrm{pH}$ and petroleum-like hydrocarbons may limit fauna, but not much is known about them. Although metal concentrations in Guaymas vent fluids are known to be lower than typical basalt-hosted systems - presumably due to the high alkalin- ity and high $\mathrm{pH}$ of the fluids that reduce metal solubility (Von Damm et al., 1985) - heavy metals may be potentially toxic in minute quantities (Decho and Luoma, 1996). In addition, a comparative study of the Guaymas and $9^{\circ} 50^{\prime} \mathrm{N}$ vents in the East Pacific Rise (EPR) showed that concentrations in metals were lower in vent fluids but higher in organism tissues at Guaymas (Von Damm, 2000; Von Damm et al., 1985). This suggests that heavy metal bioaccumulation is independent of the total metal concentrations, and depends on metal bioavailability (Ruelas-Inzunza et al., 2003; Demina et al., 2009).

\section{AOM-related microbial populations}

AOM has been shown to represent a major microbial process within both Guaymas cold seeps (Vigneron et al., 2013, 2014) and hydrothermal vents (Teske et al., 2002; Dhillon et al., 2003, 2005; Holler et al., 2011; Biddle et al., 2012). In our study, the composition of microbial communities potentially involved in AOM processes co-varied with physicochemical conditions among soft-sediment habitats. Variations were mainly related to higher ANME archaeal abundance at both seep and vent high fluid-flux habitats. Both ANME1 and ANME2 dominance increased with fluid flux intensity and thus contrast with patterns observed at the hydrate ridge methane seeps (Marlow et al., 2014a, b). There, sediment and carbonate ANME communities were related to higher dominance of ANME2 in high fluid-flux compared to low fluid-flux habitats whereas ANME1 showed the opposite pattern. Nevertheless, within our study, compositions of ANME clades were distinct between seep and vent high fluid-flux assemblages: ANME1 dominated at vent microbial mat assemblage, whereas seep microbial mats and gastropod assemblages showed co-dominance of ANME1 and 2. These results support previous studies suggesting that ANME1 is associated with higher temperatures and potentially more permanent anoxic environments compared to ANME2 (Rossel et al., 2011; Biddle et al., 2012; Vigneron et al., 2013; Holler et al., 2011; Nauhaus et al., 2005).

\section{Foundation species}

Foundation species may add heterogeneity within and between ecosystems through both allogenic and autogenic engineering (Govenar, 2010; Cordes et al., 2010). The tubes of siboglinid worms and the shells of bivalves can provide substratum and increase habitat complexity, promoting settlement or survivorship of associated species (Govenar, 2010). Vesicomyids that move vertically and laterally and, to a lesser extent, gastropods that can reach exceptionally high densities, may rework sediments, thus increasing oxygen penetration depth and indirectly promoting sulfide production (Wallmann et al., 1997; Fischer et al., 2012). In seep habitats, siboglinid tubeworms can also stimulate sulfide production through bio-irrigation and the release of sul- 
fate deep in the sediments (Cordes et al., 2005; Dattagupta et al., 2008). Alvinellid worms secrete tubes or mucus on the surfaces they colonise and may locally modify environmental conditions (fluid emission and mineral precipitation), promoting colonisation by other species (Sarrazin and Juniper, 1999; Zbinden et al., 2003; Le Bris et al., 2005; Pradillon et al., 2009). Foundation species can also foster access to highly productive habitats by providing colonisation surfaces for microbial mats and contributing to the segregation of organic matter (Levesque et al., 2005; Sarrazin et al., 2002). The level of heterogeneity provided by foundation species and the processes involved are however difficult to assess. In our study, three assemblages were characterised by the presence of common major taxa (siboglinids, vesicomyids and microbial mats), one assemblage (Hyalogyrina gastropods) was only present at seeps and another (Paralvinella alvinellids) was only present at vents. Among siboglinid assemblages, densities were 2 times higher and biomass was 14 times higher for $R$. pachyptila at vent than $E$. spicata and $L$. barhami at seep, suggesting potentially stronger engineering influence of Riftia bushes, particularly regarding habitat provision and complexity. Between seep A. gigas, seep P. soyoae and vent $A$. gigas vesicomyid assemblages, vesicomyid densities and biomasses were comparable due to high variability between samples of the same assemblage. However, visual observations of the $P$. soyoae assemblage suggest the presence of denser clusters in comparison with A. gigas clusters in seep and vent assemblages. Furthermore, the highest biomass and size were observed in $P$. soyoae. In addition, the behaviour and biological traits of the two species differ. $P$. soyoae individuals seemed restricted to the water-sediment interface in relatively compact sediments compared to $\mathrm{A}$. $\mathrm{gi}$ gas found deeply buried in soft and fine sediments. Moreover, numerous trace paths were observed around A. gigas assemblages, indicating high motility for this species. A similar pattern was observed between two vesicomyid species in the Sea of Okhotsk (Krylova, 2014): the more mobile Archivesica ochotica (a closely related species to A. gigas) was found in relatively small aggregations in soft-sediment habitats with higher sulfide fluxes, whereas, in contrast, $P$. soyoae lived in dense clusters, on more solidified sediment habitats with apparently lower fluid fluxes. A. gigas may thus have stronger allogenic effects (i.e. bioturbation), while $P$. soyoae, due to its larger size and lower motility, may have stronger authigenic effects (i.e. habitat provision).

Overall, our results showed that the Guaymas seep and vent environmental conditions are characterised by comparable concentration ranges of reduced compounds (methane, hydrogen sulfide), but they can also be differentiated in terms of type of hard substratum and vent fluid proprieties (temperature, metal, ammonium, $\mathrm{pH}$ ). These seep and vent physicochemical homologies and discrepancies influenced microbial populations linked to AOM processes in the soft-sediment habitats. Moreover, heterogeneity associated with foundation species identity may further differentiate between the two ecosystems with only one foundation species shared: the A. gigas vesicomyid. Seep and vent assemblages characterised by common major taxa, siboglinids, vesicomyids and microbial mats showed more or less comparable environmental conditions. Strong environmental differences were found among seep and vent siboglinid assemblages, with the vent assemblage showing a potentially stronger engineering role of the foundation species, with temperatures reaching $30^{\circ} \mathrm{C}$ and higher fluid-flux. In contrast, vesicomyid and microbial mat assemblages across ecosystems mainly differed in temperature at vents (vesicomyid: $6.5^{\circ} \mathrm{C}$, microbial mat: $55.5^{\circ} \mathrm{C}$ ), but showed relatively comparable fluid-flux settings (vesicomyids: low fluid-fluxes, microbial mats: high fluid-fluxes). Therefore, vesicomyid and microbial mat comparisons across ecosystems may specifically address the role of vent environmental discrepancies on macrofaunal communities.

\subsection{Community patterns and structuring factors}

Bernardino et al. (2012) proposed a conceptual framework of factors shaping the biodiversity, density and biomass of macrofaunal communities within reducing ecosystems, adapted from the Pearson and Rosenberg (1978) model. The model predicts that, within each ecosystem, density increases along a gradient of increasing fluid flux due to organic enrichment up to a threshold where fluid toxicity overwhelms the benefit of organic enrichment, thus leading to reduced densities. In parallel, the model describes a pattern of diversity as a unimodal function of fluid flux, peaking at intermediate fluid flux intensities. Low fluid intensity allows colonisation by a mix of background and chemosynthetic endemic macrofauna, whereas increasing fluid flux intensity leads to the selection of tolerant macrofauna. Likewise, many studies report that macrofaunal communities are primarily shaped by fluid flux gradients at seeps (reviewed in Levin, 2005) and vents (reviewed in Van Dover, 2000). Nevertheless, to date, no conceptual framework including compound concentrations consistent across the seep and vent ecosystems has been proposed.

\subsubsection{Density and diversity patterns}

Within both ecosystems, fluid-flux intensity depicted by methane concentrations, appears to account for a large part of the variability in faunal density. Densities at relatively low fluid-flux assemblages were enhanced in comparison with the reference and the highest densities were related to two of the high fluid-flux assemblages (vent siboglinid and seep gastropod). However, seep and vent microbial mat assemblages, which showed the highest fluid-fluxes, were characterised by reduced density. Comparison across ecosystems of microbial mat and vesicomyid assemblages did not lead to any conclusions on the vent-specific effects on density. Within both ecosystems, density variations were found among high fluid- 
flux assemblages. These differences may result from variable fluid dynamics and/or the engineering role of foundation species among assemblages whereas the nature of the substratum was not significant. While densities may reflect two dimensions on hard substrates and three dimensions on soft substrates, the foundation species add complexity to both.

Alpha diversity showed a more straightforward relationship to fluid-flux intensity through a highly significant correlation with methane concentrations. Diversity appeared to be maximal in the background sediment and decreased with increasing fluid input, highlighting enhanced selection of tolerant taxa along a gradient of fluid intensity. There were no significant diversity differences between the seep and vent ecosystems and comparisons of vesicomyid and microbial mat assemblages across ecosystems did not confirm any effect of vent-specific conditions on diversity.

Overall, our hypothesis stating that seep and vent macrofaunal communities may exhibit density and diversity patterns that are ecosystem-dependent can be rejected. Density and diversity patterns were relatively consistent with the conceptual model proposed in Bernardino et al. (2012) and suggest that seep and vent communities are similarly shaped by fluid-flux gradients without a noticeable effect of ventspecific environmental conditions. Reduced compound concentrations (methane, hydrogen sulfide) as well as other correlated factors not measured within our study, such as oxygen concentration, may be the dominant structuring factors at both seeps and vents.

\subsubsection{Community composition patterns}

We hypothesised that seep and vent macrofaunal compositions are ecosystem-dependent and more specifically, we predicted that macrofaunal overlap are larger among low fluidflux than high fluid-flux assemblages. Our results showed that the macrofaunal composition patterns did not differentiate seep from vent ecosystems. Substantial overlap was found among seep and vent assemblages characterised by low fluid inputs. The assemblages were colonised by similar families, including some that are endemic or extremely common in chemosynthetic ecosystems (e.g. neolepetopsids, provannids, lepetodrilids and polynoids), along with other families that are typical of deep-sea sediments (e.g. cirratulids, paraonids and spionids; Menot et al., 2010; Jumars et al., 2015). Surprisingly, high fluid-input assemblages were similar at seeps and vents. In both ecosystems, these assemblages were characterised by the presence of ampharetids and dorvilleids polychaetes, known as highly specialised taxa. Indeed, to cope with sulfide and/or thermal stress, ampharetid polychaetes live in vertical tubes from which they deploy their gills over and above the substrata as an adaptation to harsh environmental conditions (Treude et al., 2009; Thurber et al., 2013). In addition, ampharetids at seeps have been shown to benefit from chemosynthesis-derived nutrition (Thurber et al., 2013). Dorvilleids are known to be sulfide- tolerant and colonise sewage and other organic-rich settings (Jumars et al., 2015). Dorvilleids are usually found in the most sulfide-rich environments at seeps (Levin, 2005; Levin et al., 2013), where they have been found to exhibit multiple trophic strategies including diets specialised in chemoautotrophic microbes (Levin et al., 2013; Thurber et al., 2012). Additionally, comparison of microbial mat and vesicomyid assemblages across ecosystems did not indicate any ventspecific effect.

In addition to the community composition pattern along fluid-flux intensity, there was significant heterogeneity related to the nature of the substratum and the engineering role of the foundation species. The abundance of gastropods (lepetodrilids, neolepetopsids), polynoids, serpulids and nereidids in the siboglinid seep assemblage was significantly linked to the presence of a hard substratum. At vents, however, macrofaunal composition in the siboglinid assemblage, and to a lesser extent in the alvinellid assemblage, was not attributed to the presence of a hard substratum. With the exception of polynoids, the composition of these latter communities resembles that found in soft-substratum assemblages in high fluid-flux settings. The presence of a thick microbial mat at the base of the tubeworms R. pachyptila and of mucus in alvinellid assemblages may have fostered colonisation by soft-substratum taxa. In addition, high fluid-flux and temperatures in the siboglinid and alvinellid vent assemblages may have restricted faunal colonisation, while relatively low fluidflux at the siboglinid seep assemblage may have favoured the establishment of less tolerant taxa. Furthermore, the strong authigenic engineering effect of tubeworms at seeps may be involved. Clearly, there is a strong interplay between fluidflux intensity, substratum and engineering effects in the structuring of macrofaunal communities at seeps and vents, with the influence of the latter two factors here decreasing as fluid input increases. This hypothesis is further supported by the noticeable occurrence of lepetodrilid limpets in the seep siboglinid assemblage. Lepetodrilids are known to mainly occur at vents and the lepetodrilid L. guaymensis was first sampled and described from tubeworms and rocks of the Guaymas Southern Trough vent site (McLean, 1988). Lepetodrilid limpets have also been found in L. barhami bushes at the Jaco Scar hydrothermal seep, as were serpulids (Levin et al., 2012). In our study, the presence of these two taxa on the tubeworms $L$. barhami and E. spicata and their absence in $R$. pachyptila bushes may result from the particular setting of the sampled $R$. pachyptila assemblage as suggested by the particularly thick microbial mat at the base of the tubeworms, together with temperatures reaching ca. $30^{\circ} \mathrm{C}$, suggesting their immersion in sulfide-rich and hot fluid flux. $R$. pachyptila within the Guaymas Basin has indeed been previously observed at lower temperatures $\left(14^{\circ} \mathrm{C}\right.$; Robidart et al., 2011).

The estimation of the respective roles of fluid flux and taxon engineering on the structure of macrobenthic assemblages is often a challenge within both seep and vent 


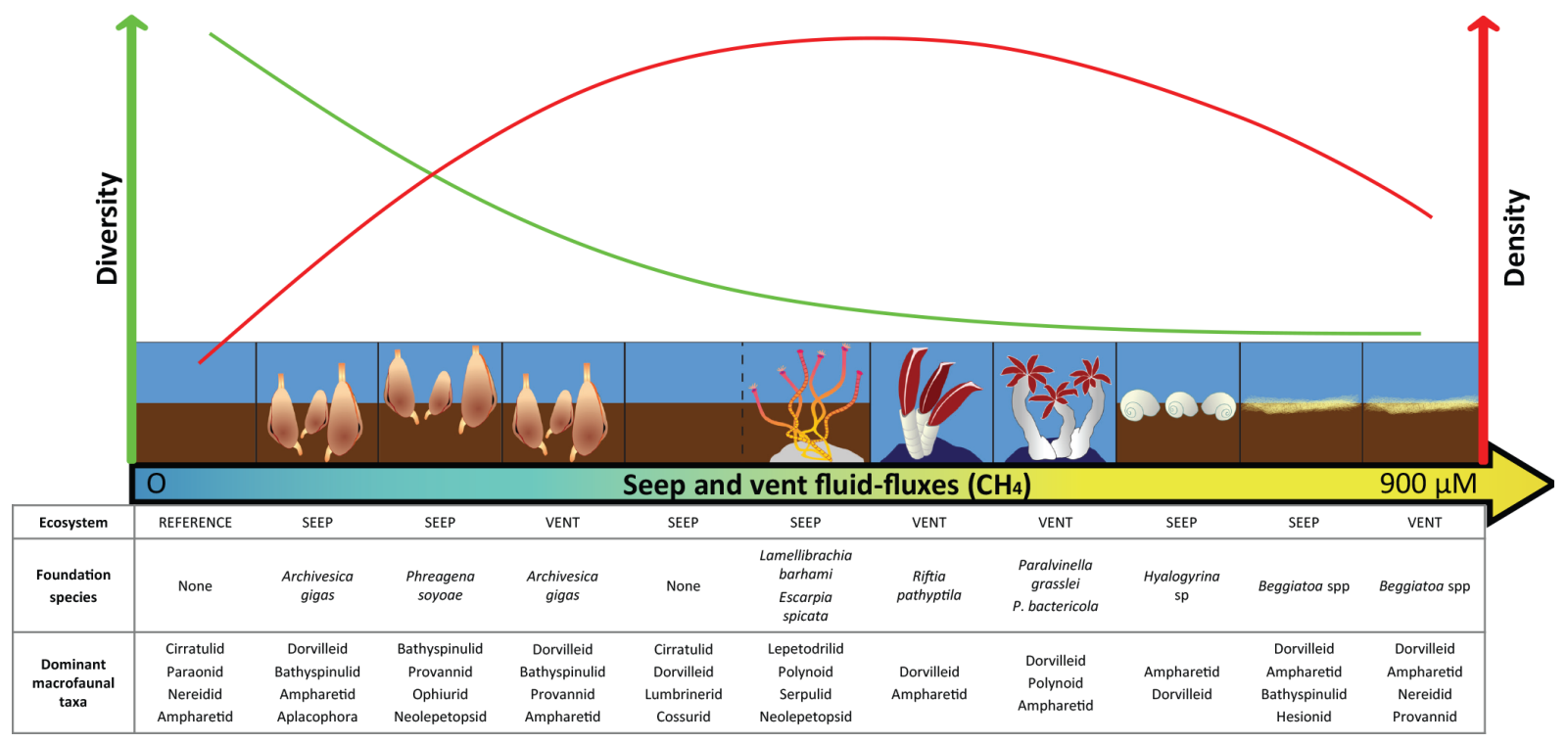

Figure 10. Conceptual diagram of macrofaunal diversity, density and composition patterns along a fluid-flux gradient in the chemosynthetic ecosystems of the Guaymas Basin.

ecosystems because the distribution of foundation species is strongly correlated with fluid flux (Cordes et al., 2009; Sahling et al., 2002; Roy et al., 2007). In our study, the presence of two distinct vesicomyid-dominated assemblages $(A$. gigas and $P$. soyoae) characterised by similar fluid fluxes among the seep ecosystem offered an opportunity to assess their respective roles in their associated communities. Considering their behavioural and biological traits, we expected A. gigas to have stronger allogenic effects (i.e. bioturbation) and $P$. soyoae to have stronger authigenic effects (i.e. habitat provision). We did indeed observe a significant structuring effect related to the $P$. soyoae in comparison with $A$. gigas. We hypothesise that sediment oxygenation by $A$. gigas accounts for colonisation by denser, species-rich endofauna dominated by polychaetes, whereas lower bioturbation activity in the P. soyoae assemblage limited the establishment of dense and diverse communities and reduced endofaunal taxa to the detriment of epifaunal Bathyspinulidae bivalve $\mathrm{Nucu}$ lana sp. Thus, these results suggest a non-negligible engineering role of foundation species in the structure of associated macrofaunal communities, here identified in low fluidflux settings. Furthermore, macrofaunal community structure variation between the two seep vesicomyid assemblages exceeded those between the seep and vent A. gigas assemblages. The engineering effect within seeps may thus overwhelm the effect of vent-specific factors.

Overall, macrofaunal community structure within Guaymas chemosynthetic ecosystems was significantly driven by fluid-flux intensity, regardless of the ecosystem (Fig. 10). Comparisons of microbial mat and vesicomyid assemblages across ecosystems further support the absence of ventspecific structuring factors. In addition, heterogeneity due to the type of substratum and the engineering role of foundation species were significant, especially within low fluid-flux settings.

\subsection{The similarity between vents and seeps}

In the Guaymas Basin, comparison of macrofaunal community composition associated with foundation species did not differentiate between seep and vent ecosystems due to the dominance of common families. Nevertheless, gamma diversity differences emerged between the seep and vent ecosystems. In total, 56 families were found at seeps and 22 at vents, leading to a dissimilarity of $42 \%$ between the two ecosystems. This value is lower than previously reported between seeps and sedimented vents in the Pacific (93\%; Bernardino et al., 2012) or around Japan (72\%; Watanabe, 2010; Nakajima et al., 2014). Dissimilarity was characterised by nestedness rather than by species turnover, because vent families represented a sub-sample of those found at seeps (i.e. all vent families were found at seeps). The higher richness found at seeps may be due to the greater sampling effort and thus, to a better characterisation of seep diversity, especially because rare species can reach up $50 \%$ of the communities in chemosynthetic environments (Baker et al., 2010). This effect of rare species is supported by the fact that 30 species from the 34 additional families at seeps were found in low relative densities $(<5 \%)$ compared with vents. Furthermore, the number of sampled sites was higher at seeps (6) than at vents (4), and high species turnover among sites is frequent at seeps (Cordes et al., 2009). A higher number of low fluid-flux assemblages were sampled at seeps (four compared with just one at vent), these being characterised by higher taxonomic 
richness and higher intrusion of background taxa. In contrast, a higher number of high fluid-flux assemblages were sampled at vents (three compared with two at seeps), which have conditions that may prevent colonisation by less tolerant taxa. In addition, the substratum and engineering effect of foundation species may have helped to enhance the beta-diversity in low fluid-flux assemblages. However, we cannot exclude the possibility that harsher and specific conditions at vents (e.g. temperature, metals) limit the colonisation of these rare macrofaunal taxa.

Shallow water studies have shown that in terms of macrofauna taxonomic richness, the family and species levels are strongly correlated (e.g. (Jameson et al., 1995; Olsgard et al., 2003). Similar conclusions have been drawn in deepsea chemosynthetic communities (Doerries and Van Dover, 2003). However, Pearson and Rosenberg (1978) suggest that increasing environmental changes are manifest at decreasing taxonomic resolutions and thus suggest that some information may still be lost in a lower range of environmental changes. Despite these limitations, species distribution across seep and vent dominant families suggests a sustained exchange between chemosynthesis-based ecosystems of the Guaymas Basin. Of the 26 species identified within 18 families, $85 \%$ were common to both ecosystems with only two species specific to seeps (Paralepetopsis sp., E. lomana) and two to vents (P. musaica, B. cupreus). These differences may even be lower because $E$. lomana, despite its absence in our vent samples, has already been collected at the Guaymas Basin vent sites (Warén and Bouchet, 1993) and P. musaica has been reported from the eastern Pacific seep site, Jalisco Block, off Mexico: (Sasaki et al., 2010). Thus, our study suggests relatively strong faunal exchanges between Guaymas seep and vent ecosystems.

In addition, the analysis of the distribution of foundation species revealed that the differences among macrofaunal communities found at the ecosystem level within our study may in fact be minimal. Of the four seep-specific foundation species (P. soyoae, E. spicata, L. barhami and Hyalogyrina sp.), two ( $P$. soyoae and E. spicata) have already been recorded at Guaymas vents (Table 7). In addition, seeprelated siboglinids have been found on authigenic carbonate crusts at an off-axis magma intrusion site within the Guaymas Northern Trough segment (Lizarralde et al., 2011). Other species found at Guaymas seeps, but not found at the vents, have already been found in other vent ecosystems: $L$. barhami has been reported in the eastern Pacific sedimented vent areas at Middle Valley (Black et al., 1997) and Hyalogyrina gastropods have been found at the periphery of microbial mats at numerous vents around the world (Sasaki et al., 2010). The absence of these assemblages within our vent study may be due to the lack of sampling at the vent periphery. While in our study $C$. pacifica was sampled at seeps only, some specimens of the species complex C. pacifica/C. lepta have previously been reported at Guaymas vents (Grassle et al., 1985; Simoneit et al., 1990). Although three vent founda- tion species, $R$. pachyptila, P. grasslei and P. bactericola, are vent-endemic, they did not appear to exert an important engineering effect on community composition in regard to their colonisation of high fluid-setting habitats.

Overall, Guaymas seep and vent species compositions suggest that, with the exception of a few species, including the foundation species that are vent-endemic, a large part of macrofaunal communities can colonise variable ecosystems and cope with environmental variations. In addition, our results contribute 20 additional species to the list of species common to seeps and vents in the world's oceans (Table 7). Our study thus provides evidence for the strong faunal similarity among reducing ecosystems in the absence of biogeographic barriers. Nevertheless, the sedimentary context of the Guaymas Basin may reduce seep and vent fluid discrepancies, allowing greater faunal exchange among ecosystems. Similar suggestion has been made for deep-sea communities around Japan, where seep and vent communities significantly differed although some vents, including the Okinawa Trough sediment vents, showed higher similarities with methane seeps than with other hydrothermal vents (Watanabe et al., 2010; Nakajima et al., 2014). Thus, more comparative studies along the seep and vent environmental continuum are needed to confirm the faunal commonality of reducing ecosystem communities.

\section{Conclusions}

Macrofaunal patterns in terms of density, alpha diversity and taxonomic composition at the family level did not differentiate the two ecosystems studied here, despite the presence of vent-specific environmental conditions. Structuring factors were found to be shared between the two ecosystems, including reduced compound concentrations, the type of substratum and the engineering role of foundation species, whereas vent-specific conditions (temperature, $\mathrm{pH}$, ammonium and metal concentrations or even observed petroleum) had no significant effect. At the ecosystem scale, higher gamma diversity at seeps than at vents mainly reflected the presence of rare taxa. These taxa may be the result of higher intrusion of background macrofauna due to higher occurrence of low fluid-flux assemblages at seeps. Seep and vent similarity may have been underestimated due to the presence of additional low fluid-flux habitats at Guaymas vent that have been reported, but were missing from our study. Species identification among seep and vent dominant families showed a high proportion of common species $(85 \%)$, highlighting that the ability of macrofauna to colonise various environmental conditions might be higher than previously suggested.

A more functional approach is currently underway to analyse the ecological processes that occur within these communities. An assessment of the food resources, ecological niches, biotic interactions and trophic adaptations within and between Guaymas vent and seep ecosystems will pave the 
way to better understanding these chemosynthetic communities.

Acknowledgements. We are grateful to the R/V L'Atalante crew for their steadfast collaboration in the success of the BIG cruise, to the chief scientist of the cruise, to the Nautile submersible pilots for their patience and constant support and to the LEP technical team for their valuable help both at sea and in the lab. We also greatly thank Anders Warén for gastropod species identification and Elena Krylova for bivalve species identification as well as helpful comments on vesicomyid taxonomy, morphology and behaviour. This cruise was funded by IFREMER (France) and held a work permit for study in Mexican waters (DAPA/2/281009/3803, 28 October 2009). This study was supported by the Laboratoire d'Excellence LabexMER (ANR-10-LABX-19) and co-funded by a grant from the French government under the Investissements d'Avenir scheme and by a grant from the Brittany Regional Council. The manuscript was professionally edited by Carolyn Engel-Gautier.

Edited by: H. Kitazato

\section{References}

Allen, J.: A new deep-water hydrothermal species of Nuculana (Bivalvia: Protobranchia) from the Guaymas Basin, Malacologia, 35, 141-151, 1993.

Arp, A. J., and Childress, J. J.: Sulfide binding by the blood of the hydrothermal vent tube worm Riftia pachyptila, Science (Wash D C), 219, 295-297, 1983.

Audzijonyte, A., Krylova, E. M., Sahling, H., and Vrijenhoek, R. C.: Molecular taxonomy reveals broad trans-oceanic distributions and high species diversity of deep-sea clams (Bivalvia: Vesicomyidae: Pliocardiinae) in chemosynthetic environments, Syst. Biodivers., 10, 403-415, 2012.

Baco, A., Smith, C., Peek, A., Roderick, G., and Vrijenhoek, R.: The phylogenetic relationships of whale-fall vesicomyid clams based on mitochondrial COI DNA sequences, Mar. Ecol.-Prog. Ser., 182, 137-147, 1999.

Baker, M. C., Ramirez-Llodra, E., Tyler, P. A., German, C. R., Boetius, A., Cordes, E., Dubilier, N., Fisher, C., Levin, L. A., and Metaxas, A.: Biogeography, Ecology and Vulnerability of Chemosynthetic Ecosystems in the Deep Sea, Life in the World's Oceans: Diversity, Distribution, and Abundance, edited by: McIntyre, A., 161-183, 2010.

Baselga, A.: Partitioning the turnover and nestedness components of beta diversity, Glob. Ecol. Biogeogr., 19, 134-143, 2010.

Baselga, A., and Orme, C. D. L.: betapart: an R package for the study of beta diversity, Meth. Ecol. Evol., 3, 808-812, 2012.

Bazylinski, D. A., Farrington, J. W., and Jannasch, H. W.: Hydrocarbons in surface sediments from a Guaymas Basin hydrothermal vent site, Org. Geochem., 12, 547-558, 1988.

Bernardino, A. F., Smith, C. R., Baco, A., Altamira, I., and Sumida, P. Y. G.: Macrofaunal succession in sediments around kelp and wood falls in the deep NE Pacific and community overlap with other reducing habitats, Deep-Sea Res. Pt. I, 57, 708-723, doi:10.1016/j.dsr.2010.03.004, 2010.
Bernardino, A. F., Levin, L. A., Thurber, A. R., and Smith, C. R.: Comparative Composition, Diversity and Trophic Ecology of Sediment Macrofauna at Vents, Seeps and Organic Falls, Plos One, 7, e33515, doi:10.1371/journal.pone.0033515, 2012.

Biddle, J. F., Cardman, Z., Mendlovitz, H., Albert, D. B., Lloyd, K. G., Boetius, A., and Teske, A.: Anaerobic oxidation of methane at different temperature regimes in Guaymas Basin hydrothermal sediments, ISME J., 6, 1018-1031, doi:10.1038/ismej.2011.164, 2012.

Black, M., Halanych, K., Maas, P., Hoeh, W., Hashimoto, J., Desbruyeres, D., Lutz, R., and Vrijenhoek, R.: Molecular systematics of vestimentiferan tubeworms from hydrothermal vents and cold-water seeps, Mar. Biol., 130, 141-149, 1997.

Black, M. B., Lutz, R. A., and Vrijenhoek, R. C.: Gene Flow among Vestimentiferan Tube Worm (Riftia-Pachyptila) Populations from Hydrothermal Vents of the Eastern Pacific, Mar. Biol., 120, 33-39, 1994.

Blake, J. A. and Hilbig, B.: Polychaeta from the vicinity of deepsea hydrothermal vents in the eastern Pacific. II. New species and records from the Juan de Fuca and Explorer Ridge systems, 1990.

Boetius, A., Ravenschlag, K., Schubert, C. J., Rickert, D., Widdel, F., Gieseke, A., Amann, R., Jorgensen, B. B., Witte, U., and Pfannkuche, O.: A marine microbial consortium apparently mediating anaerobic oxidation of methane, Nature, 407, 623-626, 2000.

Calvert, S.: Origin of diatom-rich, varved sediments from the Gulf of California, J. Geol., 546-565, 1966.

Campbell, A. C. and Gieskes, J. M.: Water column anomalies associated with hydrothermal activity in the Guaymas Basin, Gulf of California, Earth Planet. Sci. Lett., 68, 57-72, 1984.

Caprais, J.-C., Lanteri, N., Crassous, P., Noel, P., Bignon, L., Rousseaux, P., Pignet, P., and Khripounoff, A.: A new CALMAR benthic chamber operating by submersible: First application in the cold-seep environment of Napoli mud volcano (Mediterranean Sea), Limnol. Oceanogr. Methods, 8, 304-312, 2010.

Carney, R. S.: Consideration of the oasis analogy for chemosynthetic communities at Gulf of Mexico hydrocarbon vents, GeoMar. Lett., 14, 149-159, 1994.

Cordes, E. E., Arthur, M. A., Shea, K., Arvidson, R. S., and Fisher, C. R.: Modeling the mutualistic interactions between tubeworms and microbial consortia, PLoS Biol., 3, e77, doi:10.1371/journal.pbio.0030077, 2005.

Cordes, E. E., Bergquist, D. C., and Fisher, C. R.: Macro-ecology of Gulf of Mexico cold seeps, Annu. Rev. Mar. Sci., 1, 143-168, 2009.

Cordes, E. E., Cunha, M. R., Galeron, J., Mora, C., Roy, O. L., Sibuet, M., Van Gaever, S., Vanreusel, A., and Levin, L. A.: The influence of geological, geochemical, and biogenic habitat heterogeneity on seep biodiversity, Mar. Ecol., 31, 51-65, 2010.

Cruaud, P., Vigneron, A., Lucchetti-Miganeh, C., Ciron, P. E., Godfroy, A., and Cambon-Bonavita, M.-A.: Influence of DNA Extraction Method, 16S rRNA Targeted Hypervariable Regions, and Sample Origin on Microbial Diversity Detected by 454 Pyrosequencing in Marine Chemosynthetic Ecosystems, Appl. Environ. Microbiol., 80, 4626-4639, 2014.

Dahlgren, T. G., Glover, A. G., Baco, A., and Smith, C. R.: Fauna of whale falls: systematics and ecology of a new polychaete (An- 
nelida: Chrysopetalidae) from the deep Pacific Ocean, Deep-Sea Res. Pt. I, 51, 1873-1887, 2004.

Dattagupta, S., Arthur, M. A., and Fisher, C. R.: Modification of sediment geochemistry by the hydrocarbon seep tubeworm Lamellibrachia luymesi: A combined empirical and modeling approach, Geochim. Cosmochim. Ac., 72, 2298-2315, 2008.

Decho, A. W. and Luoma, S. N.: Flexible digestion strategies and trace metal assimilation in marine bivalves, Limnol. Oceanogr., 41, 568-572, doi:10.4319/lo.1996.41.3.0568, 1996.

Demina, L. L., Galkin, S. V., and Shumilin, E. N.: Bioaccumulation of some trace elements in the biota of hydrothermal fields of the Guaymas Basin (Gulf of California), Boletín de la Sociedad Geológica Mexicana, 61, 31-45, 2009.

Desbruyères, D. and Laubier, L.: Paralvinella grasslei, new genus, new species of Alvinellinae (Polychaeta: Ampharetidae) from the Galapagos rift geothermal vents, P. Biol. Soc. Wash., 95, 484-494, 1982.

Desbruyères, D. and Laubier, L.: Systematics, phylogney, ecology and distribution of the Alvinellidae (Polychaeta) from deep-sea hydrothermal vents, Ophelia, 31-45, 1991.

Dhillon, A., Teske, A., Dillon, J., Stahl, D. A., and Sogin, M. L.: Molecular Characterization of Sulfate-Reducing Bacteria in the Guaymas Basin, Appl. Environ. Microbiol., 69, 2765-2772, doi:10.1128/aem.69.5.2765-2772.2003, 2003.

Dhillon, A., Lever, M., Lloyd, K. G., Albert, D. B., Sogin, M. L., and Teske, A.: Methanogen Diversity Evidenced by Molecular Characterization of Methyl Coenzyme M Reductase A (mcrA) Genes in Hydrothermal Sediments of the Guaymas Basin, Appl. Environ. Microbiol., 71, 4592-4601, doi:10.1128/aem.71.8.4592-4601.2005, 2005.

Dinet, A., Desbruyeres, D., and Khripounoff, A.: Abondance des peuplements macro-et méiobenthiques: répartition et stratégie d'échantillonnage, Peuplements profonds du Golfe de Gascogne: campagnes Biogas. Brest: IFREMER, 121-142, 1985.

Doerries, M. and Van Dover, C.: Higher-taxon richness as a surrogate for species richness in chemosynthetic communities, DeepSea Res. Pt. I, 50, 749-755, 2003.

Dray, S. and Dufour, A.-B.: The ade4 package: implementing the duality diagram for ecologists, J. Stat. Softw., 22, 1-20, 2007.

Dubilier, N., Bergin, C., and Lott, C.: Symbiotic diversity in marine animals: the art of harnessing chemosynthesis, Nat. Rev. Microbiol., 6, 725-740, 2008.

Feldman, R. A., Shank, T. M., Black, M. B., Baco, A. R., Smith, C. R., and Vrijenhoek, R. C.: Vestimentiferan on a whale fall, Biol. Bull., 194, 116-119, 1998.

Fischer, D., Sahling, H., Nöthen, K., Bohrmann, G., Zabel, M., and Kasten, S.: Interaction between hydrocarbon seepage, chemosynthetic communities, and bottom water redox at cold seeps of the Makran accretionary prism: insights from habitatspecific pore water sampling and modeling, Biogeosciences, 9, 2013-2031, doi:10.5194/bg-9-2013-2012, 2012.

Fisher, A. and Becker, K.: Heat flow, hydrothermal circulation and basalt intrusions in the Guaymas Basin, Gulf of California, Earth Planet. Sci. Lett., 103, 84-99, 1991.

Fisher, C.: Chemoautotrophic and methanotrophic symbioses in marine-invertebrates, Rev. Aquat. Sci., 2, 399-436, 1990.

Gauthier, O., Sarrazin, J., and Desbruyeres, D.: Measure and mis-measure of species diversity in deep-sea chemosyn- thetic communities, Mar. Ecol.-Prog. Ser., 402, 285-302, doi:10.3354/Meps08395, 2010.

Gieskes, J., Kastner, M., Einsele, G., Kelts, K., and Niemitz, J.: Hydrothermal activity in the Guaymas basin, Gulf of California a synthesis, Initial reports of the deep sea drilling project, 64, 1159-1167, 1982.

Govenar, B.: Shaping Vent and Seep Communities: Habitat Provision and Modification by Foundation Species, in: The Vent and Seep Biota, edited by: Kiel, S., Topics in Geobiology, Springer Netherlands, 403-432, 2010

Grassle, J., Brown-Leger, L., Morse-Porteous, L., Petrecca, R., and Williams, I.: Deep-sea fauna of sediments in the vicinity of hydrothermal vents, B. Biol. Soc. Wash., 443-452, 1985.

Helly, J. J. and Levin, L. A.: Global distribution of naturally occurring marine hypoxia on continental margins, Deep-Sea Res. Pt. I, 51, 1159-1168, 2004.

Herzig, P. M. and Hannington, M. D.: Input from the deep: Hot vents and cold seeps, in: Marine Geochemistry, Springer, 397416, 2000.

Hessler, R. and Jumars, P.: Abyssal community analysis from replicate box cores in the central North Pacific, Deep-Sea Res., 2, 185-209, 1974.

Holler, T., Widdel, F., Knittel, K., Amann, R., Kellermann, M. Y., Hinrichs, K.-U., Teske, A., Boetius, A., and Wegener, G.: Thermophilic anaerobic oxidation of methane by marine microbial consortia, ISME J., 5, 1946-1956, doi:10.1038/ismej.2011.77, 2011.

Huber, M.: Compendium of bivalves, A full-color guide to 3,300 of the World's Marine Bivalves, A status on Bivalvia after 250 years of research, Hackenheim, Germany: ConchBooks, 901 pp., 2010.

Jameson, R., Smith, M. L., and Fairweather, P.: Sieve mesh-size and taxonomic resolution needed to describe natural spatial variation of marine macrofauna, Mar. Ecol.-Prog. Ser., 118, 187-198, doi:10.3354/meps 118187, 1995.

Jannasch, H. W. and Mottl, M. J.: Geomicrobiology of deep-sea hydrothermal vents, Scienc, 229, 717-725, 1985.

Johnson, K. S., Childress, J. J., Hessler, R. R., Sakamotoarnold, C. M., and Beehler, C. L.: Chemical and Biological Interactions in the Rose Garden Hydrothermal Vent Field, Galapagos Spreading Center, Deep-Sea Res. Pt. I, 35, 1723-1744, 1988.

Jørgensen, B. B., Zawacki, L. X., and Jannasch, H. W.: Thermophilic bacterial sulfate reduction in deep-sea sediments at the Guaymas Basin hydrothermal vent site (Gulf of California), Deep-Sea Res. Pt. I, 37, 695-710, 1990.

Julian, D., Gaill, F., Wood, E., Arp, A. J., and Fisher, C. R.: Roots as a site of hydrogen sulfide uptake in the hydrocarbon seep vestimentiferan Lamellibrachia sp, J. Exp. Biol., 202, 2245-2257, 1999.

Jumars, P. A., Dorgan, K. M., and Lindsay, S. M.: Diet of Worms Emended: An Update of Polychaete Feeding Guilds, Annu. Rev. Mar. Sci., 7, 497-520, doi:10.1146/annurev-marine010814-020007, 2015.

Kamenev, G. M.: North Pacific species of the genus Solemya Lamarck, 1818 (Bivalvia: Solemyidae), with notes on Acharax johnsoni (Dall, 1891), Malacologia, 51, 233-261, 2009.

Kawka, O. E. and Simoneit, B. R. T.: Survey of hydrothermallygenerated petroleums from the Guaymas Basin spreading center, Org. Geochem., 11, 311-328, 1987. 
Kawka, O. E. and Simoneit, B. R.: Polycyclic aromatic hydrocarbons in hydrothermal petroleums from the Guaymas Basin spreading center, Appl. Geochem., 5, 17-27, 1990.

Kindt, R. and Coe, R.: Tree diversity analysis: a manual and software for common statistical methods for ecological and biodiversity studies, World Agroforestry Centre, 2005.

Krylova, E. M.: Chemosymbiotic vesicomyids (Bivalvia: Vesicomyidae: Pliocardiinae) from cold seeps of the Sea of Okhotsk, International conference on Molluscs of the East Asia and adjacent regions, 54-55, 2014.

Krylova, E. M. and Sahling, H.: Vesicomyidae (Bivalvia): current taxonomy and distribution, PloS one, 5, e9957, doi:10.1371/journal.pone.0009957, 2010.

LaBonte, A. L., Brown, K. M., and Tryon, M. D.: Monitoring periodic and episodic flow events at Monterey Bay seeps using a new optical flow meter, J. Geophys. Res.-Sol. Ea., 112, doi:10.1029/2006jb004410, 2007.

Le Bris, N., Zbinden, M., and Gaill, F.: Processes controlling the physico-chemical micro-environments associated with Pompeii worms, Deep-Sea Res. Pt. I, 52, 1071-1083, doi:10.1016/j.dsr.2005.01.003, 2005.

Legendre, P. and Gallagher, E. D.: Ecologically meaningful transformations for ordination of species data, Oecologia, 129, 271280,2001

Legendre, P. and Legendre, L. F.: Numerical ecology, Elsevier, 2012.

Leif, R. and Simoneit, B.: Ketones in hydrothermal petroleums and sediment extracts from Guaymas Basin, Gulf of California, Org. Geochem., 23, 889-904, 1995.

Levesque, C., Limen, H., and Juniper, S. K.: Origin, composition and nutritional quality of particulate matter at deep-sea hydrothermal vents on Axial Volcano, NE Pacific, Mar. Ecol.-Prog. Ser., 289, 43-52, doi:10.3354/meps289043, 2005.

Levin, L. A.: Ecology of cold seep sediments: interactions of fauna with flow, chemistry and microbes, Oceanogr. Mar. Biol., 43, 146, 2005.

Levin, L. A. and Mendoza, G. F.: Community structure and nutrition of deep methane-seep macrobenthos from the North Pacific (Aleutian) Margin and the Gulf of Mexico (Florida Escarpment), Mar. Ecol., 28, 131-151, doi:10.1111/j.14390485.2006.00131.x, 2007.

Levin, L. A. and Sibuet, M.: Understanding Continental Margin Biodiversity: A New Imperative, Annu. Rev. Mar. Sci., 4, 79112, doi:10.1146/annurev-marine-120709-142714, 2012.

Levin, L. A., Ziebis, W., Mendoza, G. F., Growney, V. A., Tryon, M. D., Brown, K. M., Mahn, C., Gieskes, J. M., and Rathburn, A. E.: Spatial heterogeneity of macrofauna at northern California methane seeps: influence of sulfide concentration and fluid flow, Mar. Ecol.-Prog. Ser., 265, 123-139, 2003.

Levin, L. A., Orphan, V. J., Rouse, G. W., Rathburn, A. E., Ussler, W., Cook, G. S., Goffredi, S. K., Perez, E. M., Waren, A., Grupe, B. M., Chadwick, G., and Strickrott, B.: A hydrothermal seep on the Costa Rica margin: middle ground in a continuum of reducing ecosystems, P. R. Soc. B, 279, 2580-2588, doi:10.1098/rspb.2012.0205, 2012.

Levin, L. A., Ziebis, W., F. Mendoza, G., Bertics, V. J., Washington, T., Gonzalez, J., Thurber, A. R., Ebbe, B., and Lee, R. W.: Ecological release and niche partitioning under stress: Lessons from dorvilleid polychaetes in sulfidic sedi- ments at methane seeps, Deep-Sea Res. Pt. II, 92, 214-233, doi:10.1016/j.dsr2.2013.02.006, 2013.

Lizarralde, D., Soule, S. A., Seewald, J. S., and Proskurowski, G.: Carbon release by off-axis magmatism in a young sedimented spreading centre, Nat. Geosci., 4, 50-54, 2011.

Lonsdale, P. and Becker, K.: Hydrothermal plumes, hot springs, and conductive heat flow in the Southern Trough of Guaymas Basin, Earth Planet. Sci. Lett., 73, 211-225, 1985.

Lonsdale, P., Bischoff, J., Burns, V., Kastner, M., and Sweeney, R.: A high-temperature hydrothermal deposit on the seabed at a Gulf of California spreading center, Earth Planet. Sci. Lett., 49, 8-20, 1980.

Marlow, J. J., Steele, J. A., Case, D. H., Connon, S. A., Levin, L. A., and Orphan, V. J.: Microbial abundance and diversity patterns associated with sediments and carbonates from the methane seep environments of Hydrate Ridge, OR, Front. Mar. Sci., 1, 44, doi:10.3389/fmars.2014.00044, 2014a.

Marlow, J. J., Steele, J. A., Ziebis, W., Thurber, A. R., Levin, L. A., and Orphan, V. J.: Carbonate-hosted methanotrophy represents an unrecognized methane sink in the deep sea, Nat. Commun., 5, doi:10.1038/ncomms6094, 2014b.

McCollom, T. M. and Shock, E. L.: Geochemical constraints on chemolithoautotrophic metabolism by microorganisms in seafloor hydrothermal systems, Geochim. Cosmochim. Ac., 61, 4375-4391, 1997.

McLean, J. H.: New archaeogastropod limpets from hydrothermal vents; superfamily Lepetodrilacea I. Systematic descriptions, Philos. T. R. Soc. B, 319, 1-32, 1988.

Menot, L., Galeron, J., Olu, K., Caprais, J. C., Crassous, P., Khripounoff, A., and Sibuet, M.: Spatial heterogeneity of macrofaunal communities in and near a giant pockmark area in the deep Gulf of Guinea, Mar. Ecol., 31, 78-93, doi:10.1111/j.14390485.2009.00340.x, 2010.

Nakajima, R., Yamakita, T., Watanabe, H., Fujikura, K., Tanaka, K., Yamamoto, H., and Shirayama, Y.: Species richness and community structure of benthic macrofauna and megafauna in the deepsea chemosynthetic ecosystems around the Japanese archipelago: an attempt to identify priority areas for conservation, Diversity and Distributions, 1160-1172, doi:10.1111/ddi.12204, 2014.

Nauhaus, K., Treude, T., Boetius, A., and Krüger, M.: Environmental regulation of the anaerobic oxidation of methane: a comparison of ANME-I and ANME-II communities, Environ. Microbiol., 7, 98-106, 2005.

Oksanen, J., Blanchet, F. G., Kindt, R., Legendre, P., Minchin, P. R., O’Hara, R. B., Simpson, G. L., Solymos, P., Stevens, M. H. H., and Wagner, H.: vegan: Community Ecology Package, $\mathrm{R}$ package version 2.2-1, http://CRAN.Rproject.org/package= vegan, 2015.

Olsgard, F., Brattegard, T., and Holthe, T.: Polychaetes as surrogates for marine biodiversity: lower taxonomic resolution and indicator groups, Biodivers. Conserv., 12, 1033-1049, 2003.

Paull, C. K., Ussler, W., Peltzer, E. T., Brewer, P. G., Keaten, R., Mitts, P. J., Nealon, J. W., Greinert, J., Herguera, J.-C., and Elena Perez, M.: Authigenic carbon entombed in methane-soaked sediments from the northeastern transform margin of the Guaymas Basin, Gulf of California, Deep-Sea Res. Pt. II, 54, 1240-1267, doi:10.1016/j.dsr2.2007.04.009, 2007.

Pearson, A., Seewald, J. S., and Eglinton, T. I.: Bacterial incorporation of relict carbon in the hydrothermal environment of 
Guaymas Basin, Geochim. Cosmochim. Ac., 69, 5477-5486, doi:10.1016/j.gca.2005.07.007, 2005.

Petrecca, R. F. and Grassle, J. F.: Notes on fauna from several deepsea hydrothermal vent and cold seep soft-sediment communities, in: Gorda Ridge, Springer, 279-283, 1990.

Pettibone, M.: Polynoid polychaetes associated with a whale skeleton in the bathyal Santa Catalina Basin, P. Biol. Soc. Wash., 106, 678-688, 1993.

Pradillon, F., Zbinden, M., Le Bris, N., Hourdez, S., Barnay, A. S., and Gaill, F.: Development of assemblages associated with alvinellid colonies on the walls of high-temperature vents at the East Pacific Rise, Deep-Sea Res. Pt. II, 56, 1622-1631, doi:10.1016/j.dsr2.2009.05.009, 2009.

Robidart, J. C., Roque, A., Song, P., and Girguis, P. R.: Linking Hydrothermal Geochemistry to Organismal Physiology: Physiological Versatility in Riftia pachyptila from Sedimented and Basalt-hosted Vents, Plos One, 6, e21692, doi:10.1371/journal.pone.0021692, 2011.

Rossel, P. E., Elvert, M., Ramette, A., Boetius, A., and Hinrichs, K.-U.: Factors controlling the distribution of anaerobic methanotrophic communities in marine environments: evidence from intact polar membrane lipids, Geochim. Cosmochim. Ac., 75, 164184, 2011.

Roy, O. L., Caprais, J. C., Fifis, A., Fabri, M. C., Galeron, J., Budzinsky, H., Le Ménach, K., Khripounoff, A., Ondréas, H., and Sibuet, M.: Cold-seep assemblages on a giant pockmark off West Africa: spatial patterns and environmental control, Mar. Ecol., 28, 115-130, 2007.

Ruelas-Inzunza, J., Soto, L. A., and Páez-Osuna, F.: Heavy-metal accumulation in the hydrothermal vent clam Vesicomya gigas from Guaymas basin, Gulf of California, Deep-Sea Res. Pt. I, 50, 757-761, doi:10.1016/s0967-0637(03)00054-2, 2003.

Ruelas-Inzunza, J., Paez-Osuna, F., and Soto, L. A.: Bioaccumulation of $\mathrm{Cd}, \mathrm{Co}, \mathrm{Cr}, \mathrm{Cu}, \mathrm{Fe}, \mathrm{Hg}, \mathrm{Mn}, \mathrm{Ni}, \mathrm{Pb}$ and $\mathrm{Zn}$ in trophosome and vestimentum of the tube worm Riftia pachyptila from Guaymas basin, Gulf of California, Deep-Sea Res. Pt. I, 52, 13191323, 2005.

Russ, L., Kartal, B., Op Den Camp, H. J., Sollai, M., Le Bruchec, J., Caprais, J.-C., Godfroy, A., Damsté, J. S. S., and Jetten, M. S.: Presence and diversity of anammox bacteria in cold hydrocarbon-rich seeps and hydrothermal vent sediments of the Guaymas Basin, Front. Microbiol., 4, 219, doi:10.3389/fmicb.2013.00219, 2013.

Sahling, H., Rickert, D., Lee, R. W., Linke, P., and Suess, E.: Macrofaunal community structure and sulfide flux at gas hydrate deposits from the Cascadia convergent margin, NE Pacific, Mar. Ecol.-Prog. Ser., 231, 121-138, 2002.

Sahling, H., Wallmann, K. J., Dählmann, A., Schmaljohann, R., and Petersen, S.: The physicochemical habitat of Sclerolinum sp., at Hook Ridge hydrothermal vent, Bransfield Strait, Antarctica, Limnol. Oceanogr., 50, 598-606, 2005.

Salaün, P. and van den Berg, C. M.: Voltammetric detection of mercury and copper in seawater using a gold microwire electrode, Anal. Chem., 78, 5052-5060, 2006.

Sarradin, P.-M. and Caprais, J.-C.: Analysis of dissolved gases by headspace sampling gas chromatography with column and detector switching. Preliminary results, Anal. Commun., 33, 371-373, 1996.
Sarrazin, J. and Juniper, S. K.: Biological characteristics of a hydrothermal edifice mosaic community, Mar. Ecol.-Prog. Ser., 185, 1-19, doi:10.3354/meps185001, 1999.

Sarrazin, J., Robigou, V., Juniper, S. K., and Delaney, J. R.: Biological and geological dynamics over four years on a high-temperature sulfide structure at the Juan de Fuca Ridge hydrothermal observatory, Mar. Ecol.-Prog. Ser., 153, 5-24, doi:10.3354/meps153005, 1997.

Sarrazin, J., Juniper, S. K., Massoth, G., and Legendre, P.: Physical and chemical factors influencing species distributions on hydrothermal sulfide edifices of the Juan de Fuca Ridge, northeast Pacific, Mar. Ecol.-Prog. Ser., 190, 89-112, doi:10.3354/meps190089, 1999.

Sarrazin, J., Levesque, C., Juniper, S. K., and Tivey, M. K.: Mosaic community dynamics on Juan de Fuca Ridge sulphide edifices: substratum, temperature and implications for trophic structure, Cahiers De Biologie Marine, 43, 275-279, 2002.

Sasaki, T., Warén, A., Kano, Y., Okutani, T., and Fujikura, K.: Gastropods from recent hot vents and cold seeps: systematics, diversity and life strategies, in: The vent and seep biota, Springer, 169-254, 2010.

Schrader, H.: Diatom biostratigraphy and laminated diatomaceous sediments from the Gulf of California, Deep Sea Drilling Project Leg 64, Initial reports of the deep sea drilling project, 64, 973981, 1982.

Sibuet, M. and Olu, K.: Biogeography, biodiversity and fluid dependence of deep-sea cold-seep communities at active and passive margins, Deep-Sea Res. Part II, 45, 517-567, 1998.

Simoneit, B. R. T., Lonsdale, P. F., Edmond, J. M., and Shanks, W. C.: Deep-water hydrocarbon seeps in Guaymas Basin, Gulf of California, Appl. Geochem., 5, 41-49, 1990.

Simoneit, B. R. T., Leif, R. N., Sturz, A. A., Sturdivant, A. E., and Gieskes, J. M.: Geochemistry of shallow sediments in Guaymas Basin, Gulf of California: hydrothermal gas and oil migration and effects of mineralogy, Org. Geochem., 18, 765-784, 1992.

Simoneit, B. R. T., Leif, R. N., and Ishiwatari, R.: Phenols in hydrothermal petroleums and sediment bitumen from Guaymas Basin, Gulf of California, Org. Geochem., 24, 377-388, 1996.

Smith, C. and Kukert, H.: Vent fauna on whale remains, Nature, 341, 27-28, 1989.

Smith, C. R. and Baco, A. R.: Ecology of whale falls at the deep-sea floor, Oceanogr. Mar. Biol., 41, 311-354, 2003.

Smith, C. R., De Leo, F. C., Bernardino, A. F., Sweetman, A. K., and Arbizu, P. M.: Abyssal food limitation, ecosystem structure and climate change, Trends Ecol. Evol., 23, 518-528, 2008.

Smith, C. R., Bernardino, A. F., Baco, A., Hannides, A., and Altamira, I.: Seven-year enrichment: macrofaunal succession in deep-sea sediments around a 30 tonne whale fall in the Northeast Pacific, Mar. Ecol.-Prog. Ser., 515, 133-149, 2014.

Soetaert, K. and Heip, C.: Sample-size dependence of diversity indices and the determination of sufficient sample size in a highdiversity deep-sea environment, Mar. Ecol.-Prog. Ser., 59, 305307, doi:10.3354/meps059305, 1990.

Soto, L. and Grassle, J.: Megafauna of hydrothermal vents in Guaymas Basin, Gulf of California, Joint Oceanographic Assembly, Abstract, 488, 105, 1988.

Soto, L. A.: Stable carbon and nitrogen isotopic signatures of fauna associated with the deep-sea hydrothermal vent system of Guay- 
mas Basin, Gulf of California, Deep-Sea Res. Pt. II, 56, 16751682, doi:10.1016/j.dsr2.2009.05.013, 2009.

Stiller, J., Rousset, V., Pleijel, F., Chevaldonne, P., Vrijenhoek, R., and Rouse, G.: Phylogeny, biogeography and systematics of hydrothermal vent and methane seep Amphisamytha (Ampharetidae, Annelida), Integrative and comparative biology, 53, E377E377, 2013

Teske, A., Hinrichs, K. U., Edgcomb, V., de Vera Gomez, A., Kysela, D., Sylva, S. P., Sogin, M. L., and Jannasch, H. W.: Microbial Diversity of Hydrothermal Sediments in the Guaymas Basin: Evidence for Anaerobic Methanotrophic Communities, Appl. Environ. Microbiol., 68, 1994-2007, doi:10.1128/aem.68.4.1994-2007.2002, 2002.

Thurber, A. R., Levin, L. A., Orphan, V. J., and Marlow, J. J.: Archaea in metazoan diets: implications for food webs and biogeochemical cycling, ISME J., 6, 1602-1612, 2012.

Thurber, A. R., Levin, L. A., Rowden, A. A., Sommer, S., Linke, P., and Kröger, K.: Microbes, macrofauna, and methane: A novel seep community fueled by aerobic methanotrophy, 1640-1656, doi:10.4319/lo.2013.58.5.1640, 2013.

Treude, T., Smith, C. R., Wenzhöfer, F., Carney, E., Bernardino, A. F., Hannides, A. K., Krüger, M., and Boetius, A.: Biogeochemistry of a deep-sea whale fall: sulfate reduction, sulfide efflux and methanogenesis, Mar. Ecol.-Prog. Ser., 382, 1-21, 2009.

Tunnicliffe, V.: The biology of hydrothermal vents - ecology and evolution, Oceanogr. Mar. Biol., 29, 319-407, 1991.

Tunnicliffe, V. and Fowler, C. M. R.: Influence of sea-floor spreading on the global hydrothermal vent fauna, Nature, 379, 531-533, doi:10.1038/379531a0, 1996.

Tunnicliffe, V., McArthur, A. G., and McHugh, D.: A biogeographical perspective of the deep-sea hydrothermal vent fauna, Adv. Mar. Biol., 34, 353-442, doi:10.1016/s0065-2881(08)60213-8, 1998.

Tunnicliffe, V., Juniper, S. K., and Sibuet, M.: Reducing environments of the deep-sea floor, Ecosystems of the World, 81-110, 2003.

Turnipseed, M., Knick, K. E., Lipcius, R. N., Dreyer, J., and Van Dover, C. L.: Diversity in mussel beds at deep-sea hydrothermal vents and cold seeps, Ecol. Lett., 6, 518-523, doi:10.1046/j.1461-0248.2003.00465.x, 2003.

Turnipseed, M., Jenkins, C., and Van Dover, C.: Community structure in Florida Escarpment seep and Snake Pit (Mid-Atlantic Ridge) vent mussel beds, Mar. Biol., 145, 121-132, 2004.

Tyler, P. A., German, C. R., Ramirez-Llodra, E., and Van Dover, C. L.: Understanding the biogeography of chemosynthetic ecosystems, Oceanol. Ac., 25, 227-241, doi:10.1016/s03991784(02)01202-1, 2002.

Van Dover, C.: The ecology of deep-sea hydrothermal vents, Princeton University Press, 2000.

Vigneron, A., Cruaud, P., Pignet, P., Caprais, J.-C., CambonBonavita, M.-A., Godfroy, A., and Toffin, L.: Archaeal and anaerobic methane oxidizer communities in the Sonora Margin cold seeps, Guaymas Basin (Gulf of California), ISME J, 7, 1595-1608, doi:10.1038/ismej.2013.18, 2013.
Vigneron, A., Cruaud, P., Roussel, E. G., Pignet, P., Caprais, J.C., Callac, N., Ciobanu, M.-C., Godfroy, A., Cragg, B. A., Parkes, J. R., Van Nostrand, J. D., He, Z., Zhou, J., and Toffin, L.: Phylogenetic and Functional Diversity of Microbial Communities Associated with Subsurface Sediments of the Sonora Margin, Guaymas Basin, PloS one, 9, e104427, doi:10.1371/journal.pone.0104427, 2014.

Von Damm, K.: Controls on the chemistry and temporal variability of seafloor hydrothermal fluids, Seafloor Hydrothermal Systems: Physical, Chemical, Biological, and Geological Interactions, 222-247, 1995.

Von Damm, K.: Chemistry of hydrothermal vent fluids from 9-10 N, East Pacific Rise:“Time zero," the immediate posteruptive period, J. Geophys. Res.-Sol. Ea., 105, 11203-11222, 2000.

Von Damm, K. L., Edmond, J. M., Measures, C. I., and Grant, B.: Chemistry of submarine hydrothermal solutions at Guaymas Basin, Gulf of California, Geochim. Cosmochim. Ac., 49, 22212237, 1985.

Wallmann, K., Linke, P., Suess, E., Bohrmann, G., Sahling, H., Schlüter, M., Dählmann, A., Lammers, S., Greinert, J., and von Mirbach, N.: Quantifying fluid flow, solute mixing, and biogeochemical turnover at cold vents of the eastern Aleutian subduction zone, Geochim. Cosmochim. Ac., 61, 5209-5219, 1997.

Warén, A. and Bouchet, P.: New records, species, genera, and a new family of gastropods from hydrothermal vents and hydrocarbon seeps*, Zoologica Scripta, 22, 1-90, 1993.

Watanabe, H., Fujikura, K., Kojima, S., Miyazaki, J.-I., and Fujiwara, Y.: Japan: Vents and Seeps in Close Proximity, in: The Vent and Seep Biota, edited by: Kiel, S., Topics in Geobiology, Springer Netherlands, 379-401, 2010.

Weiss, V. S. and Hilbig, B.: Redescription of Ophryotrocha platykephale Blake (Polychaeta, Dorvilleidae) from the Guaymas Basin hydrothermal vents, B. South. Cal. Ac. Sci., 91, 9296, 1992.

Zal, F., Jollivet, D., Chevaldonne, P., and Desbruyeres, D.: Reproductive-Biology and Population-Structure of the DeepSea Hydrothermal Vent Worm Paralvinella-Grasslei (Polychaeta, Alvinellidae) at 13-Degrees-N on the East Pacific Rise, Mar. Biol., 122, 637-648, doi:10.1007/Bf00350685, 1995.

Zbinden, M., Le Bris, N., Compere, P., Martinez, I., Guyot, F., and Gaill, F.: Mineralogical gradients associated with alvinellids at deep-sea hydrothermal vents, Deep-Sea Res. Pt. I, 50, 269-280, doi:10.1016/s0967-0637(02)00161-9, 2003.

Zhou, J., Bruns, M. A., and Tiedje, J. M.: DNA recovery from soils of diverse composition, Appl. Environ. Microbiol., 62, 316-322, 1996. 